\title{
Combined dating of goethites and kaolinites from ferruginous duricrusts. Deciphering the Late Neogene erosion history of Central Amazonia
}

\author{
Thierry Allard ${ }^{\mathrm{a}, *}$, Cécile Gautheron ${ }^{\mathrm{b}}$, Silvana Bressan Riffel ${ }^{\mathrm{c}}$, Etienne Balan ${ }^{\mathrm{a}}$, \\ Bruna Fernandes Soares ${ }^{\mathrm{d}}$, Rosella Pinna-Jamme ${ }^{\mathrm{b}}$, Alexis Derycke ${ }^{\mathrm{b}}$, Guillaume Morin ${ }^{\mathrm{a}}$, \\ Guilherme Taitson Bueno ${ }^{\mathrm{e}}$, Nadia do Nascimento ${ }^{\mathrm{f}}$ \\ ${ }^{a}$ IMPMC, UMR CNRS 7590, Université Pierre et Marie Curie, 4 place Jussieu, F-75252 Paris cedex 05, France \\ b GEOPS, Université Paris-Sud 11, CNRS, Université Paris-Saclay, Rue du Belvédère, Bât. 504, F-91405 Orsay, France \\ ${ }^{\mathrm{c}}$ UFRGS, Federal University of Rio Grande do Sul, Av. Bento Gonçalves, 9500, Institute of Geosciences, 91509-900 Porto Alegre, Brazil \\ d Pontifícia Universidade Católica de Minas Gerais - Pós Graduação de Geografia, Av. Itaú, 505 - Prédio Emaús - Dom Cabral, Belo Horizonte, Minas Gerais CEP: \\ 30535012, Brazil \\ e UFG, IESA, Federal University of Goias, Av. Esperança, s/n, Samambaia, Goiânia, GO, 74001-970, Brazil. \\ ${ }^{\mathrm{f}}$ UNESP, State University of São Paulo, Av. 24 A, 15, Bela Vista, Rio Claro, SP, Brazil
}

\section{A R T I C L E I N F O}

\section{Editor: Dr. G. Jerome}

Keywords:

Laterite

Duricrust

Goethite (U-Th)/He

Kaolinite EPR

Dating

Amazonia

\begin{abstract}
A B S T R A C T
This study focuses on the dating of millimetric pisoliths from ferruginous duricrusts located in central Amazonia (Brazil), by coupling detailed mineralogy and two relevant dating methods: (i) (U-Th)/He analysis of goethites by mass spectrometry; (ii) analysis of radiation-induced defects of kaolinites embedded in duricrusts by electron paramagnetic resonance spectroscopy (EPR). Three samples collected at different elevations in the landscape were selected. The goethite corrected ages range from 1.1-15.2 Ma and consistently increase with elevation. EPR was performed on kaolinites after several cycles of a deferration procedure. Considering extreme geochemical scenarii, the ages of kaolinites are 1.7-7.1 Ma for a closed system and 4.0-16.7 Ma for an open system with 100\% Rn loss. Ages of goethites and kaolinites are close, in the limit of the uncertainty of the methods. They show important periods of duricrust formation at Middle Miocene and at Late Miocene/Pliocene. Data allow the estimation of lowering rates between 3 and $8 \mathrm{~m} / \mathrm{Ma}$, in agreement with independent data available in the literature for the central Amazonia region or even for erosion of other cratons in the world. The two dating methods can be compared on common duricrust samples. By revealing single or multi-step weathering/erosion episodes related to relictual paleosurfaces, they also bring promising contributions to an advanced knowledge of ancient and complex lateritic geosystems.
\end{abstract}

\section{Introduction}

Soils are important compartments of the critical zone and witnesses of past climates through mineral or isotopic markers, such as hematite/ goethite ratio, presence of a Fe-duricrust or $\delta^{18} \mathrm{O}$ and $\delta \mathrm{D}$, respectively (Girard et al., 2000, 2002; Tardy, 1997; Tardy and Roquin, 1998; Yapp, 2000; Beauvais, 1999; Beauvais and Roquin, 1996; Beauvais and Tardy, 1993; Zhao et al., 2017). They are also agents of climates, especially through $\mathrm{CO}_{2}$ consumption by $\mathrm{Ca}$ - and $\mathrm{Mg}$-silicate weathering (Berner et al., 1983). Major geochemical processes of weathering are known and exhibit climatic zonation at the global scale (Nahon, 1991; Pedro, 1987). In particular, laterites and lateritic soils are forming or preserved as relicts on circa $1 / 3$ of the global continental surfaces and represent $80 \%$ of the soil volumes (Nahon, 2003). Hence, they represent deeply weathered materials of major significance. Laterites can reach several tens of meters and exhibit a simple mineralogy mainly composed of kaolinite, iron and aluminum oxides sensu lato as well as relicts of parent minerals such as quartz and ancillary minerals (McFarlane, 1976; Nahon, 1991; Tardy and Nahon, 1985). A frequent feature of laterites is the development of a ferruginous duricrust at the top of the profiles, which can be overlaid with other soil horizons. These duricrusts cover the flat reliefs of planation surfaces of different ages and elevation and behave as landmark levels that attest major phases of weathering and erosion in geomorphological sequences at regional and even continental scale (Beauvais and Chardon, 2013; Beauvais et al., 2016; Bonnet et al., 2014, 2016; Théveniaut and Freyssinet, 1999, 2002).

Absolute dating of lateritic duricrusts remains an important and

\footnotetext{
* Corresponding author.

E-mail address: thierry.allard@upmc.fr (T. Allard).
} 


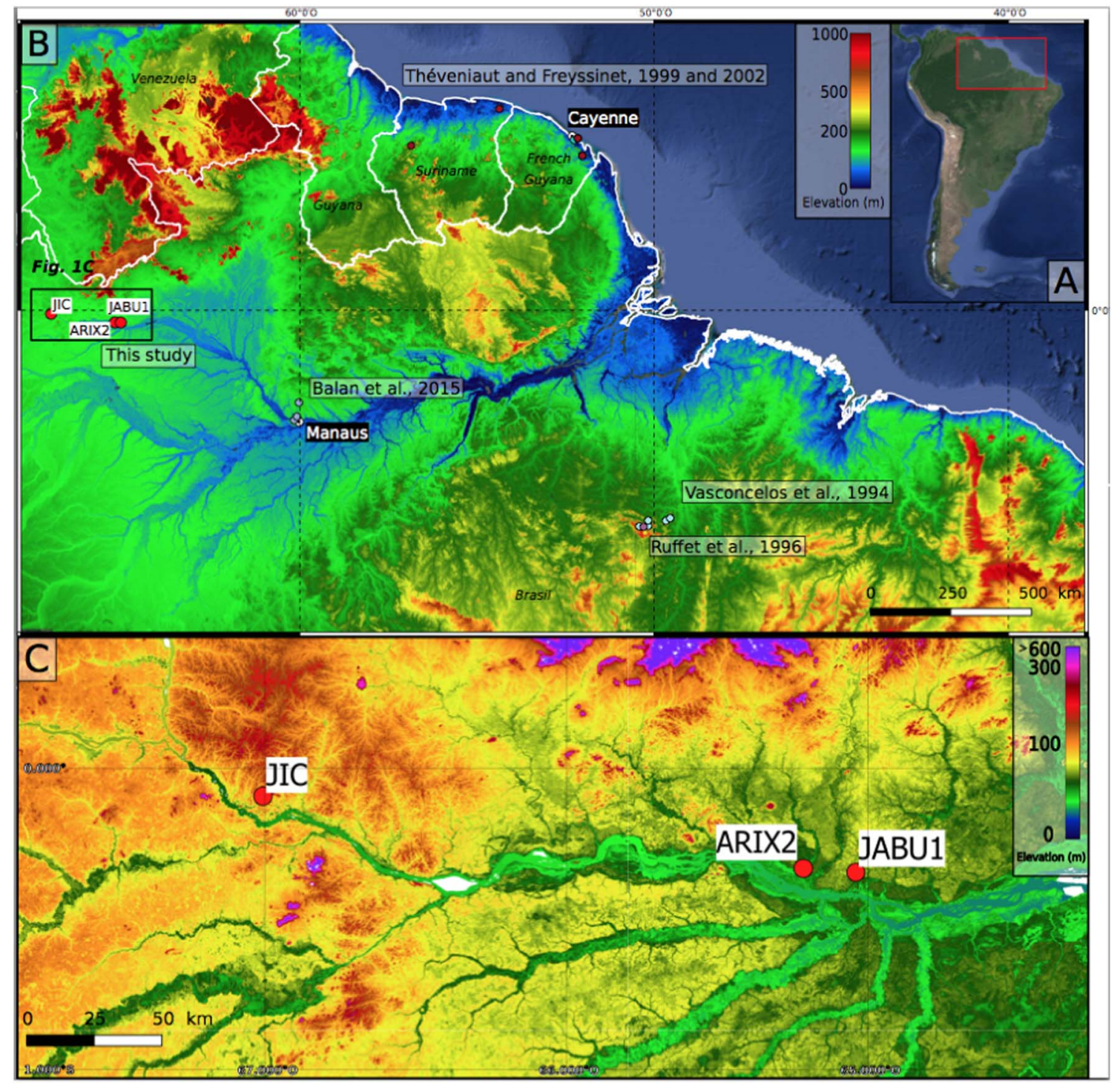

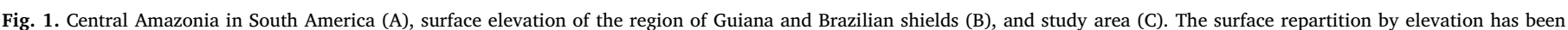

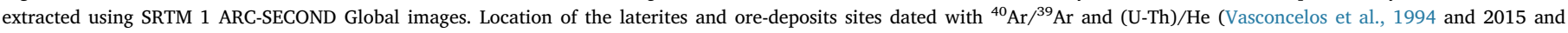
reference therein), EPR (Balan et al., 2005), paleomagnetism (Théveniaut and Freyssinet, 1999, 2002), together with the 3 sites from this study.

challenging task for constraining the evolution of continental surfaces and the relation of their formation with paleoclimates or geodynamics. As a matter of fact, these weathering covers are composed of multiphased minerals for which the chronology has long been poorly documented (Cornu et al., 2009; Nahon, 2003). The first attempts of absolute dating of iron oxides by palaeomagnetism demonstrated that laterites could be older than expected (Cenozoic-Mesozoic) even if the method presented a relatively poor resolution (see e.g., Schmidt and Embleton, 1976). In more recent times, three main new dating methods were developed that apply to secondary components of the soil and are consistent with geological time scales $>1$ Ma (Cornu et al., 2009). The first one mainly relies on the measurement of the ${ }^{40} \mathrm{Ar} /{ }^{39} \mathrm{Ar}$ ratio on $\mathrm{K}$ bearing manganese oxides, using laser ablation technique on single grains (Beauvais et al., 2008, 2016; Bonnet et al., 2014, 2016; Vasconcelos, 1999; Vasconcelos et al., 1994, 2013, 2015). This approach provided an outlook of continuous, ancient weathering with clear discrete episodes irregularly distributed from the end of Mesozoic to present. In some cases, data could be correlated to paleoclimatic parameters such as global continental drainage (Tardy and Roquin, 1998) or global deep-sea temperature derived from $\delta^{18} \mathrm{O}$ data (Zachos et al., 2001; Bonnet et al., 2016). The two other methods apply to ubiquitous mineral components of laterites, i.e. iron oxides and kaolinite. Iron oxyhydroxides and oxides such as goethite and hematite can be dated using the (U-Th)/He method, coupled with the ${ }^{4} \mathrm{He} /{ }^{3} \mathrm{He}$ and (U-Th)/Ne methods, which requires relatively coarse (i.e. circa $\mathrm{mm}$ ) grains to avoid significant diffusion effects of He out of the crystals (e.g. Farley, 2002; Farley and Flowers, 2012; Gautheron et al., 2006; Pidgeon et al., 2004; Shuster et al., 2005). In addition, kaolinite formation can be dated using electron paramagnetic resonance spectroscopy (EPR) of the point defects (electron holes on oxygen atoms of the structure) produced by radioactivity (Allard et al., 2012). This was performed on laterites from the Manaus region (Central Amazonia) and provided ages from Paleogene - at depth - to Pliocene in the topsoils (Balan et al., 2005). The use of these two last methods confirmed that laterites could be deep seated in Cenozoic times.

The main objectives of this study are a first inter-comparison of the (U-Th)/He and EPR dating methods on common samples and the discussion of derived lowering rates with respect to those determined in the literature from independent methods. In addition, relation with geological events will be tentatively discussed. We focus on three lateritic duricrust relicts from the Central Amazon region (Brazil), where samples from distinct elevation were collected and contain millimeter- 
sized pisoliths. The region exhibits ferruginous duricrusts in lateritic profiles (Costa et al., 2014; Costa and Moraes, 1998), but their absolute dating and correlation with the paleosurfaces already identified in South America (King, 1962; Bardossy and Aleva, 1990; Tardy and Roquin, 1998; Rossetti et al., 2005; Théveniaut and Freyssinet, 2002) remain undocumented. Bedrocks include granitoid basement and the Neogene Içá Formation, which are the most extended outcrops of the Central Amazon basin (Fritsch et al., 2007).

\section{Geological and chronological context of central Amazonia}

\subsection{Geology}

Since the break-up of Gondwanaland, several periods of uplift, denudation, and climate change have modified the landscape in Amazonia region. Periods of uplift took place in the Paleogene (Central Andes), Late Oligocene-Early Miocene (Northern Andes) with posterior reactivations in the Miocene ( $\sim 12 \mathrm{Ma})$ and Pliocene $(\sim 4.5 \mathrm{Ma})$ (Hoorn et al., 2010). These events have affected the landscape by promoting accelerated denudation, controlling hydrographic basins, increasing clastic input into the adjacent margin. The stratigraphic column for Amazon Basin shows unconformities underlying and overlying the Upper Cretaceous Alter do Chão Formation followed by lateritization. This suggests periods of quiescent tectonic conditions and favorable climate resulting in low denudation rates and development of weathering profile (Horbe et al., 2013).

The Guiana and Brazilian shields constitute northern and southern elevated landforms from either side of the Amazon river (Fig. 1). The corresponding shield is composed of Paleozoic sediments (Prosperança and Trombetas formations) lying on Precambrian crystalline rocks including granites, migmatites, greenstones, and metasedimentary rocks (Kroonenberg and Roever, 2010). In addition, more recent sandy and clayey sediments with varying clay content cover the major part of central Amazonia. The unconsolidated to poorly consolidated fluviallacustrine sediments from Alter do Chão and Solimões formations rest on Paleozoic rocks (Cunha et al., 2007). Based on the paleontological record, the Alter do Chão Formation corresponds to a Cretaceous-Paleogene sequence (Cunha et al., 1994; Daemon, 1975; Dino et al., 2012; Horbe et al., 2003), whereas the Solimões Formation corresponds to Middle Miocene (12-11 Ma, Cozzuol, 2006; Dino et al., 2012; Latrubesse et al., 2007). The Phanerozoic Solimões Basin sets between highlands of the Brazilian and Guiana shields in the southern and northern boundaries, respectively. It is limited towards the west by the Iquitos Arch and towards the east by the Purus Arch. The Purus Arch acts as a topographic divide in the Miocene controlling the sedimentation of Solimões Formation and some rivers flow eastwards (Milani and Zalan, 1999). The period when Amazonas River established its current course and onset the Amazonas Fan is still debated but would have occurred at most during Miocene at $\sim 11$ Ma (Figueiredo et al., 2009; Figueiredo et al., 2007; Heinrich and Zonneveld, 2013; Horbe et al., 2013). An extensive area of central Amazonia is covered by the Içá Formation (9.5-2.5 Ma), which occurs around 100-140 m a.s.l. and lies unconformably on the Solimões Formation (Campbell et al., 2006). This formation is analogous to the Peruvian Madre de Dios Formation set between the Ucayali peneplanation unconformity, that marks the Quechua II tectonic phase at Miocene, and the Pleistocene-Holocene deposits, both dated by trapped ash deposits in sediments (Campbell et al., 2006; Horbe et al., 2013; Rossetti et al., 2005). Weathering occurred in the different formations throughout the Amazon Basin. However, the ages of corresponding laterites are still poorly constrained, preventing the construction of a comprehensive model of the weathering in this region of the tropical world.

In the studied area, the main outcrops include granitoid rocks from various formations (as Uaupés, Tapuruquara, Curicuriari, Marauia, Maié-Mirim, Igarapé Reilau, Cauaburi) and also the Neogene Içá sedimentary formation (Fig. 2). The related rocks correspond to the most extended outcrops of the Central Amazon basin, as stated by Fritsch et al. (2007).

\subsection{Chronology of weathering/erosion surfaces}

The central Amazonia region displays a subdue topography with dissected low plateaus (up to $100-180 \mathrm{~m}$ a.s.l.) and surrounding surfaces having higher elevation (up to $600 \mathrm{~m}$ ), as illustrated in Fig. 1B. Those surfaces are mainly composed of laterites developed on Paleozoic to the Archean basement and on clastic sedimentary rocks (Fritsch et al., 2011; Ishida et al., 2014; Lucas et al., 2012). A scattered patchwork of a few absolute ages is available for lateritic formations from the central Amazonia (Fig. 1B). In the region of Manaus, up to four Quaternary terraces overlying the Içá Formation were identified by Rossetti et al. (2005) using ${ }^{14} \mathrm{C}$ dating. EPR dating of kaolinites from latosols located near Manaus yielded Pliocene/Miocene ages (older than $5 \mathrm{Ma}$ ) for the topsoil and Paleogene ages, i.e. higher than about $20 \mathrm{Ma}$ for the weathering of underlying sediments of Alter do Chão Formation (Balan et al., 2005). Besides, using present dissolution kinetics of quartz, Irion (1984) suggested a minimum age of 5 Ma for the laterites developed on the Barreiras Formation, which is correlated to the Alter do Chão Formation, corroborating the ages of laterite kaolinites obtained by Balan et al. (2005).

On the Brazilian Shield, several authors detailed a K-Ar and ${ }^{40} \mathrm{Ar} /{ }^{39} \mathrm{Ar}$ geochronology on manganese oxides from lateritic profiles including ore-deposits developed on Archean and Proterozoic bedrocks from the Serra dos Carajás (Pará) (Ruffet et al., 1996; Vasconcelos et al., 1994, 2015). The samples were located on high elevation surfaces ( $>300 \mathrm{~m}$ a.s.l; Fig. 1). Those data revealed multiple generations of the oldest ages (about 70-65 Ma) corresponding to the Cretaceous period. In addition, ferruginous duricrusts from this region were also dated by (U-Th)/He and yielded ages ranging from 70 to $1 \mathrm{Ma}$ (Shuster et al., 2012; Vasconcelos et al., 2015). Besides the similar ages recorded by ${ }^{40} \mathrm{Ar} /{ }^{39} \mathrm{Ar}$ and $(\mathrm{U}-\mathrm{Th}) / \mathrm{He}$ methods, the authors claimed that the results show preferential periods of lateritization, indicating changes in physico-chemical conditions with time. Although located outside central Amazonia, iron duricrusts from Quadrilátero Ferrífero (Minas Gerais) show various ${ }^{40} \mathrm{Ar} /{ }^{39} \mathrm{Ar}$, (U-Th)/He ages reaching the Eocene epoch (Carmo and Vasconcelos, 2006; Monteiro et al., 2014; Shuster et al., 2012). In addition, old cosmogenic ${ }^{3} \mathrm{He}$ isotopic ages suggested a long stability with respect to erosion since $20 \mathrm{Ma}$ (Shuster et al., 2012).

On the Guiana Shield, laterites and bauxites occur associated with flat surfaces at an elevation around $150 \mathrm{~m}$ a.s.l. (Théveniaut and Freyssinet, 1999, 2002). The palaeomagnetism method reveals periods favorable to ferruginous duricrust formation at Paleocene-Eocene and Miocene that correspond to Sul-americana and Velhas paleosurfaces recognized at the scale of the South American continent, respectively (Théveniaut and Freyssinet, 1999, 2002).

From the above-mentioned chronology, it appears that relictual laterites and duricrusts from the Amazonia region can be relatively old, with some periods of formation deeply seated in Cenozoic or even Mesozoic. In addition, ${ }^{40} \mathrm{Ar} /{ }^{39} \mathrm{Ar}$ ages of Mn-oxides show discrete rather than continuous periods of weathering for the Amazon Basin, which raises the question of their origin. However, it is not yet clearly known if specific periods of formation of duricrusts in the Amazon Basin can be related to climatic (global or regional) or geodynamic events, although some interpretations of chronometric data have been proposed (e.g. Tardy and Roquin, 1998). Other chronometers consistent with the geological time scale and related to ubiquitous secondary minerals of laterites (i.e. kaolinite, iron oxides), such as those used in our study, also appear relevant to address these issues. 


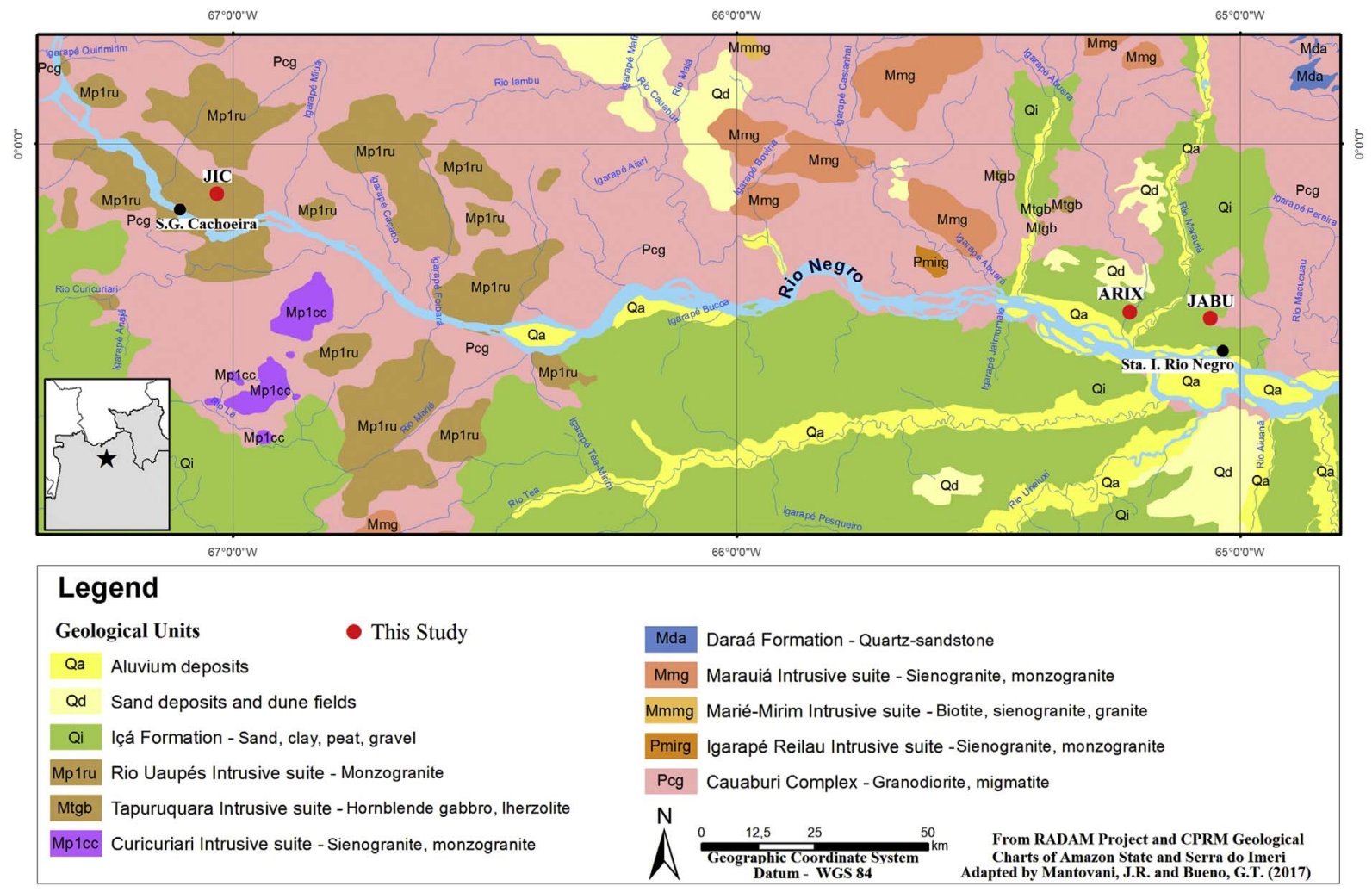

Fig. 2. Geological map of the studied region in central Amazonia (CPRM, 2006).

\section{Sampling and methods}

\subsection{Sampling sites}

In 2012 and 2013, fieldworks covered a regional area between the cities of Barcelos and São Gabriel da Cachoeira in the central Amazon region, searching for landmarks which could be correlated to the Feduricrusts previously recognized in the Guiana Shield by Théveniaut and Freyssinet (1999, 2002). Then, among all duricrust occurrences, three sites were selected according to the presence of pisoliths and to their topographic position (Fig. 1C, Table 1). Photographs of the sampling sites in the field are reported in the supplementary information (Fig. SI-1). The materials from Santa Isabel do Rio Negro region originate from two geological formations (Fig. 2): the Neogene sediments of Içá Formation (CPRM, 2006) for the sample ARIX2 and the granodiorites of Cauaburi Complex (Guiana Shield), for the sample JABU1. JABU duricrust is at the summit of a flat top hill that corresponds to the dominant regional geomorphic surface and that was part of a continuous planation surface (Fig. SI-2a). The sample JABU1 was collected at $60 \mathrm{~m}$ elevation, close to Jabuti stream. Locally, the iron-duricrust was covered by $100 \mathrm{~cm}$ of unconsolidated lateritic soil containing pisoliths. The ARIX duricrust is located at the Arixana river bank, on the water level, and therefore it is in an altimetric level inferior to that of the planation surface (Fig. SI-2a). The ARIX2 sample was collected at $46 \mathrm{~m}$ elevation where the iron-duricrust was outcropping. No evidence of allochthonous origin was found in the field. Assuming autochthonous origin, the ARIX2 duricrust formed after erosion by the Arixana river of the paleosurface related to JABU1.

The sample from the São Gabriel da Cachoeira region was collected near the Jeriqueiro locality and is named JIC. JIC and JABU duricrusts are both located on the summit of flat top hills that were part of a continuous planation surface (Figs. SI-2a and SI-2b), possibly the Velhas surface (King, 1956; Horbe et al., 2001). This surface is being dissected by the Rio Negro and its tributaries. JIC originates from a $210 \mathrm{~cm}$ depth in a lateritic profile (Fig. SI-1) developed on the crystalline Precambrian basement (monzogranites of Rio Uaupés intrusive suite) of the Guiana Shield (Fig. 2). The laterite profile presents a typical coloration and structure and is located at an elevation of $90 \mathrm{~m}$ (Table 1, Fig. 1C).

\subsection{Mineralogical and crystallographic description}

Mineralogical and crystallographic properties of the samples were characterized using optical and scanning electron microscopes along with X-ray diffraction. The mineral assemblage and semi-quantitative chemical composition were analyzed on carbon-coated thin sections using a field emission SEM Zeiss ULTRA55 microscope coupled with a Bruker QUANTAX device for Energy-Dispersive X-ray Spectra (EDS). Powder X-ray diffraction patterns were recorded with the Co Ka radiation wavelength on a Panalytical X'Pert Pro diffractometer equipped with the X'celerator detector, in the $5-140^{\circ} 2 \theta$ range. The Rietveld refinement (XND code; Berar and Baldinozzi, 1998) was used to determine the relative mineralogical composition of oxides (iron oxides

Table 1

Location of the ferruginous duricrusts.

\begin{tabular}{|c|c|c|c|c|c|}
\hline Sample & Latitude (S, WGS84) & Longitude (W, WGS84) & Elevation (m) & Sampling & Bedrock \\
\hline ARIX2 & $00^{\circ} 20^{\prime} 32.0^{\prime \prime}$ & $65^{\circ} 12^{\prime} 50.4^{\prime \prime}$ & 46 & At surface & Içá Formation \\
\hline JABU1 & $00^{\circ} 20^{\prime} 39.6^{\prime \prime}$ & $65^{\circ} 02^{\prime} 48.6^{\prime \prime}$ & 60 & $1 \mathrm{~m}$ depth & Precambrian basement (granite) \\
\hline JIC & $00^{\circ} 05^{\prime} 54.7^{\prime \prime}$ & $67^{\circ} 00^{\prime} 45.3^{\prime \prime}$ & 90 & $2.1 \mathrm{~m}$ depth & Precambrian basement (monzogranite) \\
\hline
\end{tabular}


Table 2

Crystallographic data, and mean coherent domain size (MCD along crystallographic directions) of Goethite.

\begin{tabular}{|c|c|c|c|c|c|c|c|}
\hline Sample & Goethite (\%) & Gibbsite (\%) & Quartz (\%) & Lepidocrocite (\%) & $\operatorname{MCD}[100](n m)^{a}$ & MCD [010] (nm) & $\operatorname{MCD}[001](\mathrm{nm})$ \\
\hline \multicolumn{8}{|c|}{ Santa Isabel do Rio Negro } \\
\hline ARIX2 & 76 & - & 22.4 & 1.3 & 14 & 13 & 17 \\
\hline JABU1 & 100 & - & - & - & 20 & 20 & 24 \\
\hline \multicolumn{8}{|c|}{ São Gabriel da Cachoeira } \\
\hline JIC & 76.6 & 14.4 & 9 & - & 16 & 15 & 21 \\
\hline
\end{tabular}

${ }^{a}$ MCD values were determined using a Rietveld treatment.

and quartz) in the samples as well as the size of mean coherent domains, which is derived from the width of diffraction peaks along selected directions using the Scherrer formula (Bish and Post, 1989). All corresponding information is reported in Table 2.

\section{3. (U-Th)/He dating}

The principle of the (U-Th)/He dating method relies on the ${ }^{4} \mathrm{He}$ production, ejection and accumulation inside the crystal structure during the alpha decay of the radioactive U-Th chains (Farley, 2002). (U-Th)/He ages were determined by measuring the total He content of the samples and in a second step, the total $U$ and Th content. The raw (U-Th)/He age was then calculated using the $\mathrm{He}, \mathrm{U}$ and Th content and knowing the radioactive periods of ${ }^{238} \mathrm{U},{ }^{235} \mathrm{U}$ and ${ }^{232} \mathrm{Th}$. No correction of alpha ejection has been considered here, because the mean alpha stopping distance of the ejected $\mathrm{He}$ in iron oxides and hydroxides ranging from 14 to $16 \mu \mathrm{m}$ (Ketcham et al., 2011), is small compared to the samples size (circa $1 \mathrm{~mm}$ ). On the other hand, He can be lost by diffusion due to the polycrystalline nature of the millimetric samples (e.g., Shuster et al., 2005; Vasconcelos et al., 2013). A loss between 5 and $30 \%$ of He by diffusion is generally estimated for goethite (e.g. Shuster et al., 2005; Vasconcelos et al., 2013; Monteiro et al., 2014; Riffel et al., 2016). A possible loss by diffusion in our samples will be estimated in the result section.

The samples were cleaned using an ultrasonic bath for several hours to remove the matrix, and rinsed with milli-Q water. Single pisolith grains were selected under a binocular microscope; weighed and encapsulated into a niobium foil (Purity 99.9\%). The grains presented a rounded shape and weighed between 8.1 and $11.3 \mathrm{mg}$. The helium content was measured in the low-temperature thermochronology laboratory at GEOPS (Orsay, France). Each encapsulated sample was degassed using a diode Ytterbium laser under vacuum for $30 \mathrm{~min}$ at $1000{ }^{\circ} \mathrm{C}$. This procedure was repeated until all ${ }^{4} \mathrm{He}$ was degassed, without any loss of U or Th (Vasconcelos et al., 2013). The ${ }^{4} \mathrm{He}$ gas was mixed in the purification line with a known amount of ${ }^{3} \mathrm{He}$ used as a spike, and purified from most of the $\mathrm{H}_{2} \mathrm{O}, \mathrm{CO}_{2}, \mathrm{H}_{2}$, Ar gases using three liquid nitrogen-cooled traps of activated charcoal, ST707 and ST701 SAES-getters. Helium isotopes $\left({ }^{3} \mathrm{He}\right.$ and $\left.{ }^{4} \mathrm{He}\right)$ in addition to these gases were measured in the Pfeiffer Prisma Quadrupole mass spectrometer to ensure the purity of the analytical gas (see Gautheron et al., 2013, for more details). After degassing, the samples were extruded from the tube directly into $5 \mathrm{~mL}$ Teflon-capped vials for complete dissolution. Firstly, $100 \mathrm{~mL}$ of $5 \mathrm{M} \mathrm{HNO}_{3}$ containing a known amount of ${ }^{235} \mathrm{U}$ and ${ }^{230} \mathrm{Th}$ was introduced in each vial followed by $200 \mathrm{~mL}$ of $30 \% \mathrm{HCl}$, and a few drops of $38 \% \mathrm{HF}$. The vials were closed and heated up to $70{ }^{\circ} \mathrm{C}$ overnight. The solutions were evaporated at $180^{\circ} \mathrm{C}$ to concentrate the sample. If the sample was not completely dissolved, the procedure of adding $\mathrm{HCl}$ and $\mathrm{HF}$ was repeated. Secondly, $5 \mathrm{~mL}$ of $5 \mathrm{M} \mathrm{HNO}_{3}$ was added in the final solution and heated for $1 \mathrm{~h}$ at $100^{\circ} \mathrm{C}$. The solution was diluted with $1 \mathrm{M} \mathrm{HNO}_{3}$ to set the iron content at $100 \mathrm{ppm}$. Eventually, $\mathrm{U}$ and Th measurements were undertaken by using a quadrupole ICP-QMS series ${ }^{\text {II }}$ CCT Thermo-Electron at LSCE (Gif sur Yvette, France).

All results including (U-Th)/He ages are reported in Table 3. The analytical error for $\mathrm{He}$ and U-Th measurements is $5 \%$ at 1 o. The diffusion corrected age was estimated by using a helium production/ diffusion code (Ketcham, 2005). The associated error has been computed and represents $15 \%$ at 1 o including the $5 \%$ analytical error. This value is slightly higher than the one usually taken of $10 \%$ (e.g. Vasconcelos et al., 2013).

\subsection{Electron paramagnetic resonance (EPR) dating}

\subsubsection{Purification of kaolinites}

Kaolinite was purified by removing iron oxides according to the following procedure. First, duricrust samples were ground into a fine powder with an agate mortar and pestle. Then the samples (about $100 \mathrm{~g}$ each) were treated by several (at least 10) cycles to remove the iron from the solution using a citrate-dithionite-bicarbonate reagent (Mehra and Jackson, 1960). This procedure is necessary to minimize the interference of iron oxides with the radiation-induced defect (RID) signal during the EPR analysis. Sedimentation column method was used to separate the clay size $(<2 \mu \mathrm{m})$ fraction and concentrate kaolinite.

\subsubsection{EPR spectra measurement}

Electron paramagnetic resonance spectroscopy (EPR) is a very sensitive (down to the atomic ppm), selective, and non-destructive method devoted to examination of paramagnetic species, i.e. those having unpaired electron(s), such as ions of transition elements (like $\left.\mathrm{Fe}^{3+}, \mathrm{V}^{4+}, \mathrm{Mn}^{2+}, \mathrm{Cr}^{3+}\right)$, rare earth elements, organic-free radicals, or radiation-induced defects (RIDs) in minerals (Calas, 1988). It is based upon the absorption of a quantum of microwave energy favored by the splitting of specific spin energy levels under a magnetic field. EPR spectra were recorded on kaolinite powder samples at X-band $(\approx 9.4 \mathrm{GHz})$ at $\sim 118 \mathrm{~K}$ using a Bruker EMXplus ${ }^{\mathrm{TM}}$ spectrometer. Samples were analyzed at low temperature to minimize the contribution of residual iron oxides, provided that they behave as super-paramagnetic species. As a matter of fact, iron oxides are often associated with kaolinite as nanometric and super-paramagnetic phases, causing their EPR amplitude to decrease with decreasing temperature (Muller and Calas, 1993). The acquisition parameters were set as 3-5 G for modulation amplitude and $40 \mathrm{~mW}$ for microwave bridge power. All spectra were normalized for sample mass, recording gain and a constant resonant cavity filling-factor. Species revealed by EPR are characterized by a specific so-called "g factor". EPR spectra of RIDs were defined by their effective $g$ values derived from the resonance condition:

$h v=g \times \beta \times H_{0}$

where $h$ is the Planck constant $\left(6.625 \times 10^{-34} \mathrm{Js}\right), \nu$ is the resonance frequency (MHz), $\beta$ is the Bohr magneton $\left(9.274 \times 10^{-24} \mathrm{JT}^{-1}\right)$, and $H_{o}$ is the external magnetic field (mT). The principal values of $g$ were calibrated using a 2,2-diphenyl-1-picrylhydrazyl (DPPH) standard $\left(g_{\text {DPPH }}=2.0036\right)$ with an accuracy of 0.001 . The spectrum of the dominant, stable, so-called A-center used for dating typically exhibits two main components named $g_{/ /}$and $g_{\perp}$ with known values (Clozel et al., 1994).

The concentrations of radiation-induced defects (RIDs) in kaolinite were estimated from a measurement of the maximum amplitude of the perpendicular component (located at $g_{\perp}$ ) in the $3300-3700 \mathrm{G}$ range and 
Table 3

(U-Th)/He results.

\begin{tabular}{|c|c|c|c|c|c|c|c|c|}
\hline Samples & Weight & ${ }^{4} \mathrm{He}$ & $\mathrm{U}$ & Th & $\mathrm{eU}$ & $\mathrm{Th} / \mathrm{U}$ & Age $\pm 1 \sigma$ & Corrected age $\pm 1 \sigma$ \\
\hline & $(\mathrm{mg})$ & (ncc/g) & $(\mathrm{ppm})$ & $(\mathrm{ppm})$ & $(\mathrm{ppm})$ & & (Ma) & (Ma) \\
\hline \multicolumn{9}{|c|}{ Santa Isabel do Rio Negro } \\
\hline ARIX2-A & 9.1 & 2585 & 10.1 & 4.5 & 11.2 & 0.4 & $2.0 \pm 0.1$ & $2.4 \pm 0.4$ \\
\hline ARIX2-B & 9.0 & 3999 & 21.2 & 3.4 & 22.0 & 0.2 & $1.6 \pm 0.1$ & $1.9 \pm 0.3$ \\
\hline ARIX2-C & 8.6 & 4291 & 17.2 & 7.2 & 18.9 & 0.4 & $1.9 \pm 0.1$ & $2.3 \pm 0.3$ \\
\hline ARIX2-D & 8.8 & 3947 & 10.4 & 7.6 & 12.2 & 0.7 & $2.7 \pm 0.1$ & $3.2 \pm 0.5$ \\
\hline ARIX2-E & 8.6 & 3329 & 15.6 & 3.7 & 16.5 & 0.2 & $1.7 \pm 0.1$ & $2.0 \pm 0.3$ \\
\hline \multirow[t]{2}{*}{ ARIX2-F } & 8.1 & 2810 & 13.4 & 4.7 & 14.5 & 0.4 & $1.6 \pm 0.1$ & $1.9 \pm 0.3$ \\
\hline & & & & & & Mean age & $1.9 \pm 0.4$ & \\
\hline JABU1-A & 10.5 & 3101 & 7.5 & 4.9 & 8.7 & 0.6 & $3.1 \pm 0.2$ & $3.7 \pm 0.6$ \\
\hline JABU1-B & 10.1 & 2143 & 5.2 & 3.6 & 6.1 & 0.7 & $3.0 \pm 0.2$ & $3.6 \pm 0.5$ \\
\hline JABU1-C & 11.1 & 2717 & 4.3 & 3.8 & 5.2 & 0.9 & $4.3 \pm 0.2$ & $5.2 \pm 0.8$ \\
\hline JABU1-D & 9.8 & 2659 & 5.6 & 3.7 & 6.5 & 0.7 & $3.4 \pm 0.2$ & $4.1 \pm 0.6$ \\
\hline JABU1-E & 9.6 & 2910 & 6.1 & 3.8 & 7.0 & 0.6 & $3.4 \pm 0.2$ & $4.1 \pm 0.6$ \\
\hline \multirow[t]{2}{*}{ JABU1-F } & 11.1 & 2849 & 6.0 & 4.1 & 7.0 & 0.7 & $3.4 \pm 0.2$ & $4.1 \pm 0.6$ \\
\hline & & & & & & Mean age & $3.4 \pm 0.5$ & \\
\hline \multicolumn{9}{|c|}{ São Gabriel da Cachoeira } \\
\hline JIC-A & 10.2 & 1743 & 14.7 & 8.3 & 16.7 & 0.6 & $0.9 \pm 0.01$ & $1.1 \pm 0.2$ \\
\hline JIC-B & 10.9 & 9143 & 13.8 & 6.5 & 15.4 & 0.5 & $5.1 \pm 0.3$ & $6.1 \pm 0.9$ \\
\hline JIC-C & 9.6 & 4188 & 12.8 & 4.9 & 14.0 & 0.4 & $2.5 \pm 0.1$ & $3.0 \pm 0.5$ \\
\hline JIC-D & 10.2 & 5632 & 5.6 & 51.5 & 18.0 & 9.1 & $2.6 \pm 0.1$ & $3.1 \pm 0.5$ \\
\hline JIC-E & 10.6 & 7275 & 5.7 & 60.1 & 20.1 & 1.0 & $8.5 \pm 0.4$ & $10.2 \pm 1.5$ \\
\hline JIC-F & 10.5 & 15,371 & 7.7 & 104.4 & 32.8 & 1.3 & $12.7 \pm 0.6$ & $15.2 \pm 2.3$ \\
\hline \multirow[t]{2}{*}{ JIC-G } & 11.3 & 4877 & 4.9 & 88.2 & 26.1 & 1.6 & $6.0 \pm 0.3$ & $7.2 \pm 1.1$ \\
\hline & & & & & & Mean age & $5.5 \pm 4.1$ & \\
\hline
\end{tabular}

Table 4

Dosimetry parameters for EPR dating of kaolinite.

\begin{tabular}{|c|c|c|c|c|c|c|c|c|}
\hline Sample & $\mathrm{U}(\mathrm{ppm})$ & Th (ppm) & $\mathrm{K}(\mathrm{ppm})$ & Paleodose (kGy) & $\begin{array}{l}\text { Dose rate, Closed system (mGy/ } \\
\text { ka) }\end{array}$ & $\begin{array}{l}\text { Dose rate Open system (mGy/ } \\
\text { ka) }\end{array}$ & $\begin{array}{l}\text { Age closed } \\
\text { (Ma) }\end{array}$ & Age open (Ma) \\
\hline ARIX2 & $10.68 \pm 10 \%$ & $5.22 \pm 10 \%$ & $0.08 \pm 15 \%$ & $64 \pm 38 \%$ & $36,827 \pm 10 \%$ & $16,023 \pm 10 \%$ & $1.7 \pm 0.8$ & $4.0 \pm 1.9$ \\
\hline JIC & $11.49 \pm 10 \%$ & $25.28 \pm 5 \%$ & $0.02 \pm 15 \%$ & $398 \pm 20 \%$ & $55,651 \pm 8 \%$ & $23,849 \pm 8 \%$ & $7.2 \pm 2.0$ & $16.7 \pm 4.7$ \\
\hline
\end{tabular}

expressed in arbitrary units (Table 4). Despite the presence of several RIDs in the same region of the EPR spectrum, this simplified approach is valid because the shape of the signal is similar between samples and by far dominated by the most stable defect (the A-center). The error on the RID concentration is around $\pm 10 \%$, taking into account the mass, positioning in the cavity, and apparatus deviation.

\subsubsection{Paleodose determination}

The paleodose is determined using a calibrating curve obtained experimentally through artificial irradiations that simulate the effect of natural ionizing radiations. The irradiations were performed with $1.5 \mathrm{MeV} \mathrm{He}^{+}$ions on the ARAMIS particle accelerator (CSNSM, Orsay, France). The kaolinite samples were deposited and dried on stainless steel circular plates, forming a $4 \mu \mathrm{m}$-thickness layer, which refers to the range of $\mathrm{He}^{+}$ions in the clay mineral as calculated with the SRIM code (Ziegler et al., 2010). The fluences were between $3 \times 10^{11}$ and $1 \times 10^{13} \mathrm{ions} / \mathrm{cm}^{2}$, corresponding to doses of $70-2342 \mathrm{kGy}$, a range that is appropriate to obtain the dosimetry curves and determine paleodoses in soils (Balan et al., 2005). The minimum error per dose was $\pm 5 \%$. After irradiation, the samples were heated at $250{ }^{\circ} \mathrm{C}$ for $2 \mathrm{~h}$ to anneal unstable defects, according to the procedure of Allard and Muller (1998).

The growth curve of concentration of RIDs as a function of dose can most often be fitted by an exponential function that provides the paleodose (Hennig and Grün, 1983):

$[C]=\left[\mathrm{C}_{\mathrm{s}}\right] \times(1-\exp (-\lambda(\mathrm{D}+\mathrm{P}))$

where $[\mathrm{C}]$ is the concentration of A-centers (arbitrary units), $\left[\mathrm{C}_{\mathrm{s}}\right]$ is the concentration at saturation (arbitrary units), $\lambda$ is an exponential efficiency factor $\left(\mathrm{Gy}^{-1}\right), \mathrm{D}$ is the artificial dose (Gy) and $\mathrm{P}$ is the paleodose, i.e. the dose naturally cumulated by the sample since its formation. The unit of dose is the Gray ( $1 \mathrm{~Gy}=1 \mathrm{~J} / \mathrm{kg}$ ).

When necessary, a linear component must be added to the exponential function (Duval, 2012).

\subsubsection{Dose rate determination}

The dose rate was calculated using the concentrations of the main sources of radiations, i.e. arising from $U$ and $T h$ decay chains and from ${ }^{40} \mathrm{~K}$, together with the elementary dose-rates provided by Aitken (1985). The content of U, Th and K was measured on raw samples ground below $80 \mu \mathrm{m}$, by ICP-AES and ICP-MS techniques, at the SARM (CRPG, Nancy, France). Analytical details and errors on measurements are described at http://www.crpg.cnrs-nancy.fr/SARM/index.html. Two corrections of the dose rate were considered, the first one being related to the possible geochemical aperture of the radioactive system and the second one to the microscopic distribution of uranium with respect to kaolinite particles (see below).

Uranium and thorium decay chains include several daughters with specific geochemical behaviors (Ivanovich and Harmon, 1992). One critical issue is the possible escape of radon (Rn), an inert and very mobile gas produced in ${ }^{238} \mathrm{U},{ }^{235} \mathrm{U}$ and ${ }^{232} \mathrm{Th}$ decay chains. This mobility can induce a substantial decrease (up to about one half) of dose rate, because of the loss of the Radon daughters by the system. Loss of $\mathrm{Rn}$ in «Fe laterite» has been reported as low as 3\% by Sakoda et al. (2011), but this can probably be much higher as it is expected to depend on the evolution of porosity during the lifetime of the iron duricrust. Consequently, in absence of detailed information about the evolution of porosity, two extreme scenarii of $100 \%$ Rn loss (considered as a worst case for an open system) and $0 \% \mathrm{Rn}$ loss (closed system) were taken into account to calculate dose rates and bracket the possible ages 
of kaolinite trapped in the duricrust.

A second correction, related to dose rate, can also be determined from the mapping of uranium at a microscopic scale in case of heterogeneous U content. This was performed on ARIX2 and JIC samples by induced fission tracks (Price and Walker, 1963). Polished thin sections were covered with a Kapton foil and irradiated with a thermal neutron flux provided by the FRMII reactor, Munich, Germany, according to the procedure by Sélo (1983). A cumulative flux of $6.9 \times 10^{15}$ neutrons $/ \mathrm{cm}^{2}$ was used during the irradiation. The fission tracks formed in the Kapton foils were revealed through the reaction with a hypochlorite solution $(14 \% \mathrm{NaClO}$ and $12 \% \mathrm{NaCl})$ at $100{ }^{\circ} \mathrm{C}$ for $9 \mathrm{~min}$. Then, the tracks were counted using an optical microscope with an $\times 1000$ magnification. Homogeneity of the neutron flux was verified using a standard of $50 \mathrm{ppm}$ of uranium in glass provided by the National Institute of Standards and Technology.

\subsubsection{EPR age determination}

Specifically, the EPR ages were determined using the following equation:

Age $=$ Paleodose $/$ Dose-rate

Dating kaolinites trapped in a duricrust implies to take into account a specific chronology. Indeed, as stated by several authors, the duricrust formation can be subsequent to the kaolinite formation and not necessarily synchronous (Nahon, 1991; Tardy, 1997). To handle this issue, we assume here that the duricrust not only trapped the kaolinites but also the radioelements responsible for the radioactivity experienced by the clay mineral. According to this assumption, the dose rate was nearly the same before and after the duricrust formation. If the kaolinites crystallized before the duricrust, then the age of the clay minerals will be obviously higher than that of the iron oxides, provided that it exceeds the error range of the method.

The error on the age value was calculated from the errors on paleodose and dose-rate according to a formalism detailed in the supplementary information (Table SI-3).

\section{Results}

\subsection{Mineralogical and crystallographic characterization}

Optical microscope observations of the three selected samples reveal concentric rings of iron oxides without nuclei in the pisolith centers (Fig. 3A-F). A more complex structure has been observed in the JIC sample where discontinuities along the rings crosscut the outer concentric layers, indicating dissolution or mechanical reworking followed by precipitation of iron oxides. In addition, SEM analysis of this sample shows that pisoliths are coated with a homogeneous layer of goethite and cemented with iron oxides. Consequently, in JIC, several generations of iron oxides are evidenced: some occur within the pisoliths either as concentric or discontinuous millimetric layers, some as a uniform cortex and some as cement. These observations of unconformity of iron oxide growth rings suggest a possible allochthonous origin of the JIC cuirass. By contrast, the microscopic observations of ARIX2 and JABU1 suggest an in situ formation. In those samples, the pisoliths are more homogeneous and a bulky matrix cementing them is observed, resulting in a massive structure (Fig. 3A, F). The ARIX2 sample has a massive structure whose the matrix represents about $25 \%$ of the duricrust volume, according to the optical microscope observations. The JABU1 sample is also massive with most volume occupied by the pisoliths and the JIC sample has an iron oxide cortex around pisoliths developing some porosity and less frequent matrix.

By SEM, iron oxide crystallites were not clearly detected within the pisoliths, where the structure is massive, whereas close to the pores they most often present a measurable size, with remarkable growth patterns (see ARIX2 picture in Fig. 4A). In the two samples studied by EPR, kaolinite could not be directly detected by SEM except as coarse crystals embedded in iron oxides of a fragment with an irregularly rounded shape in JIC (Fig. 4B). The large booklets of kaolinite are consistent with conditions of formation linked to the saprolite, as observed for the Alter do Chão transformed sediment overlaid by a latosol in the Manaus region (Balan et al., 2005) or for lowermost levels of eastern Amazon kaolin deposits (Costa et al., 2009). This indicates a relatively old episode of weathering because these kaolinites are now clearly above the present saprolite. In addition, significant and varying concentrations of $\mathrm{Si}, \mathrm{Al}, \mathrm{P}$ could also be measured by EDS in pisoliths or in the matrix of ARIX2, suggesting the possible presence of kaolinites not evidenced probably because of their small size.

$\mathrm{X}$-ray diffraction showed that kaolinite is a minor phase in the three samples (Fig. 5). The Rietveld refinement of XRD patterns allowed the determination of the iron oxide mineralogy and the corresponding dimension of mean coherent domains (MCD). In all cases, goethite was the main iron oxide (from 76 to $100 \%$ ), whereas quartz only occurred in the JIC and ARIX2 samples. The mean coherent domain sizes were small and of the same order of magnitude for the three samples (13-24 nm). The largest domains corresponded to the JABU1 sample and the smallest to the ARIX2 sample (Table 2).

Photographs of typical induced fission tracks distribution are shown in Fig. 3B and D for the samples ARIX2 and JIC, respectively. In both cases, the fission tracks are homogeneously distributed within the pisoliths, whose shape is readily recognized in a matrix merely devoid of tracks. Fission tracks of a few U-bearing phases are observed through their typical "urchin-like" morphology. The proportion of uranium in discrete U-bearing phases in JIC is around $0.8 \%$ of the total U content for JIC and $0.2 \%$ for ARIX2, which is negligible. Hence, a correction of the dose rate is not required and full alpha contribution must be taken into account (Aitken, 1985).

\section{2. $(U-T h) / H e$ data}

(U-Th)/He ages were obtained in six to seven pisolith grains from each sample made mostly of goethite. No alpha ejection correction was applied to the yielded ages because the pisoliths were pre-selected to a minimum dimension ( 0.5 to $1 \mathrm{~mm}$ ), excluding the possibility of any significant He loss (Ketcham et al., 2011). The yielded ages were homogeneous for both the ARIX2 and JABU1 samples and ranged from $1.6 \pm 0.1$ to $2.7 \pm 0.1 \mathrm{Ma}(\mathrm{n}=6)$ and from $3.0 \pm 0.2$ to $4.3 \pm 0.2 \mathrm{Ma}(\mathrm{n}=6)$, respectively. In addition, the Th/ $\mathrm{U}$ ratio of individual pisolith grains were quite homogeneous and lower than 1 , as illustrated in Fig. 6A. This result attests to the homogeneity of the samples, as the $\mathrm{Th} / \mathrm{U}$ ratio can be used to trace any difference in iron oxide populations or the presence of inclusions (Monteiro et al., 2014; Riffel et al., 2016). However, the JIC sample that comes from São Gabriel da Cachoeira region yielded a more dispersed range of raw (UTh)/He ages, from $0.9 \pm 0.1$ to $12.7 \pm 0.6 \mathrm{Ma}(\mathrm{n}=7)$. The Th/U ratio also varies from 0.4 to 9.1 (Fig. 6A), suggesting several generations of goethite, in agreement with the heterogeneity observed by microscopy (Fig. 3). The effective uranium content ( $\mathrm{eU}=\mathrm{U}+0.24 \mathrm{Th}$ ) that corresponds to the content of all ${ }^{4} \mathrm{He}$ emitters in the grains is however quite significant, ranging from 5.2 to $22.0 \mathrm{ppm}$ for the Santa Isabel do Rio Negro samples (ARIX2 and JABU1) and from 14.0 to $32.8 \mathrm{ppm}$ for the São Gabriel da Cachoeira JIC sample (Table 3, Fig. 6B).

\subsection{EPR data}

Several species are identified on the total EPR spectra of ARIX2 and JIC that are characteristic of kaolinites (Fig. 7A). The structural $\mathrm{Fe}^{3+}$ of kaolinite, i.e. substituting for $\mathrm{Al}^{3+}$ in octahedral sites of the structure, appears at low magnetic field (Balan et al., 1999). Two signals, socalled $\mathrm{Fe}(\mathrm{I})$ and $\mathrm{Fe}(\mathrm{II})$, compose the structural $\mathrm{Fe}^{3+}$ spectrum (Balan et al., 1999), the relative contribution of which reveals that JIC kaolinite is clearly well crystallized when compared to ARIX2, consistently 

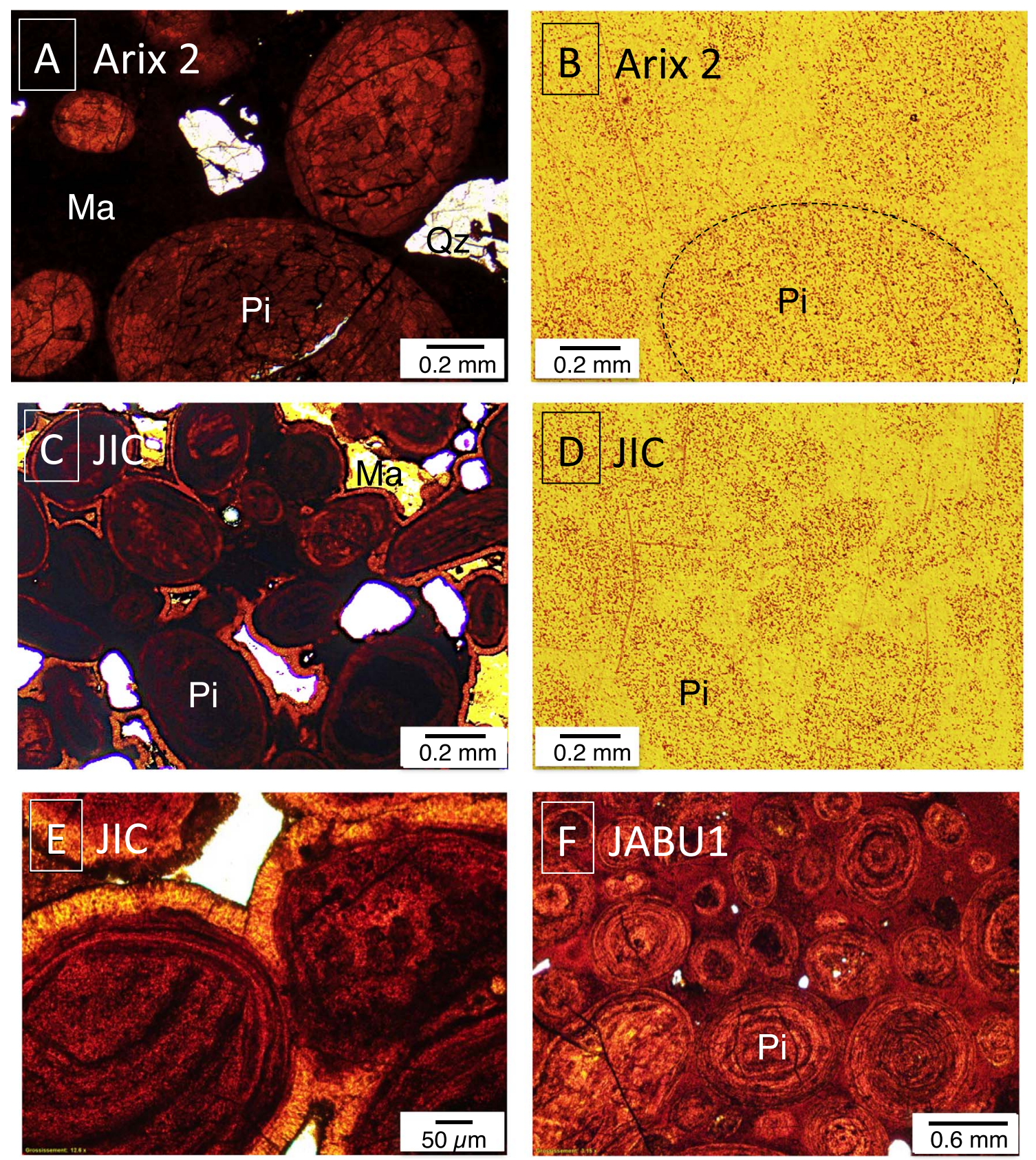

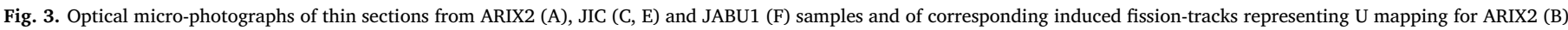

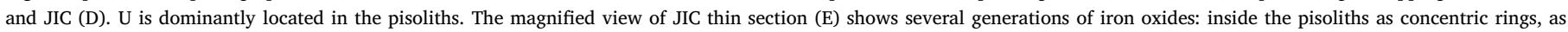
unconformity structure and at the surface as a uniform cortex. Ma: matrix; Pi: pisolith.

with the SEM observation of large booklets in JIC. This also indicates that the conditions of formation of these two kaolinites were different, resulting in two distinct generations with a different crystalline order. The signal responsible for the baseline is assigned to iron oxides that remained trapped in kaolinite particles after the deferration procedure (Muller and Calas, 1993). A narrow doublet was observed at the high magnetic field in the region of radiation-induced defects of kaolinite, and reported in an enlarged view in Fig. 7B. This doublet is characteristic of the dominant axial spectrum of the A-center, with components occurring at $g_{/ /}=2.049$ and $g \perp=2.002$. The ARIX2 sample also exhibits a weak axial spectrum of vanadyl complex $\left(\mathrm{VO}^{2+}\right)$ (Muller and Calas, 1993) that is superimposed on the signal of RIDs. Consequently, the RID concentration may be slightly overestimated for ARIX2 but cannot present a strong deviation because in the dosimetry curve (Fig. 8) the first point corresponding to the natural sample is not aberrantly high. The RIDs spectrum of JABU1 was too small to be unequivocally identified (not shown): the parallel component was not visible and there was a significant additional shoulder in the perpendicular component region. Furthermore, this sample could not be prepared for irradiation because of its hydrophobic behavior. Consequently, the JABU1 kaolinite sample could not be dated by EPR in this study.

The relation of A-center concentration with the irradiation dose for ARIX2 and JIC are plotted in Fig. 8. The paleodoses corresponds to $64 \pm 24 \mathrm{kGy}$ and $398 \pm 80 \mathrm{kGy}$, for the ARIX2 and JIC samples respectively, as determined by the fitting procedure. Table 4 shows the dose-rate calculated from the concentrations of radioelements by reference to elementary dose-rates for extreme scenarii of closed and open systems for U, Th and K, as formulated by Aitken (1985). The open system corresponds to a scenario of $100 \%$ radon loss, Rn being a very 


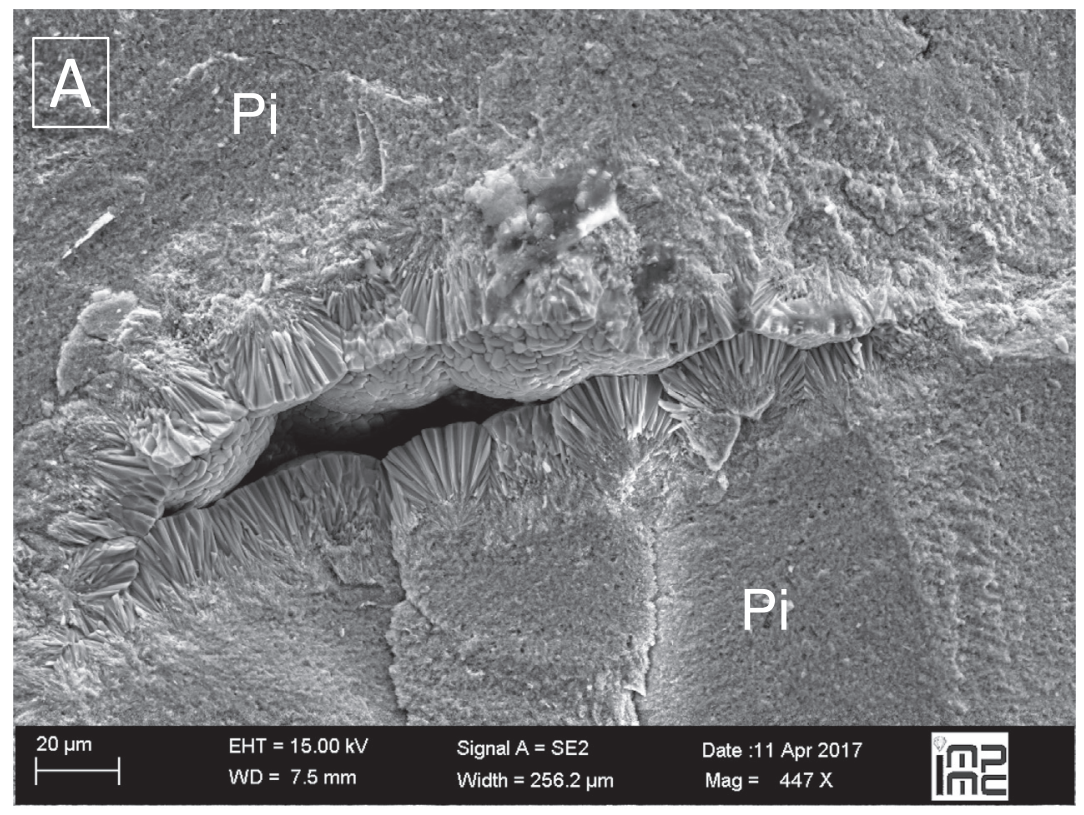

Fig. 4. Scanning electron microscopy: Pisoliths with a massive structure of goethite and layer of bunch goethite crystallites in the porosity of ARIX2 (A). Coarse kaolinite crystals embedded in a Fe oxide nodule from JIC sample (B).

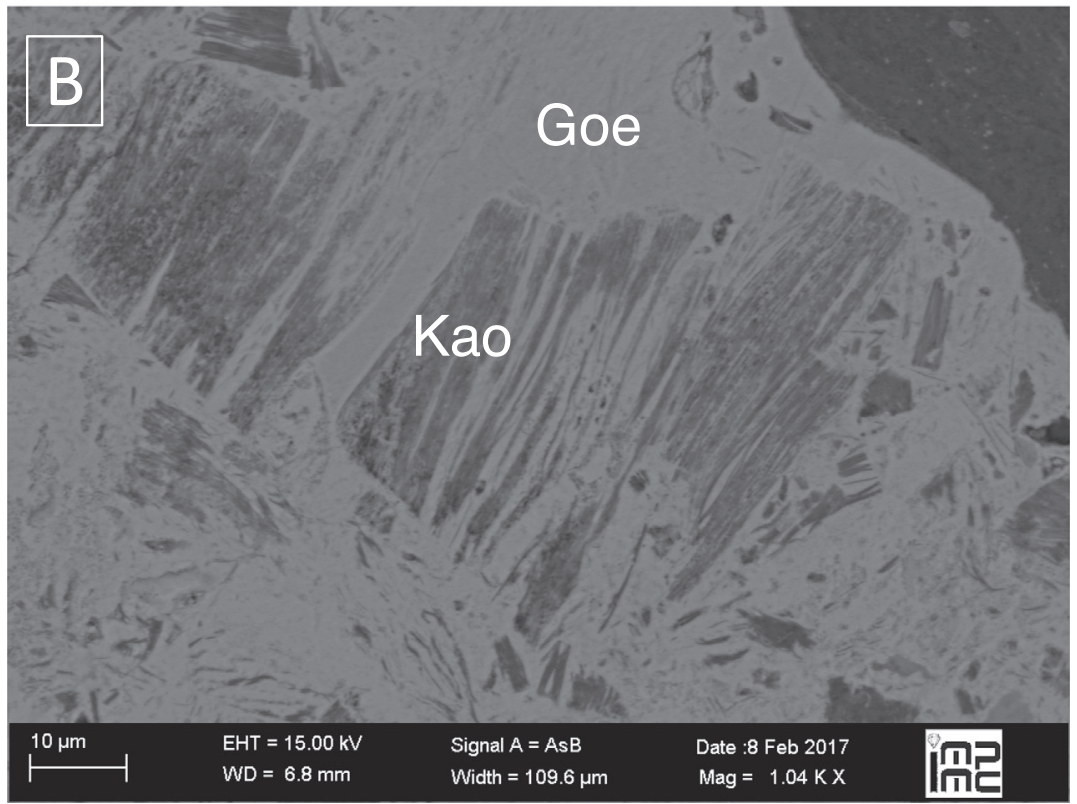

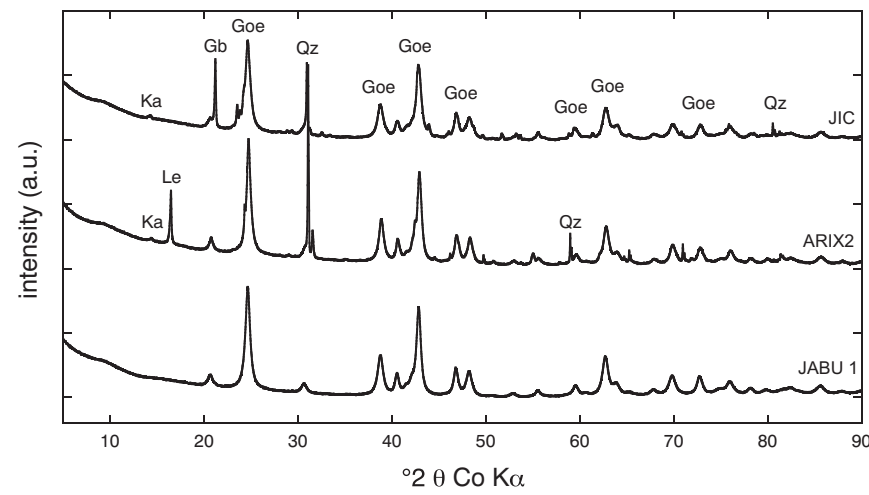

Fig. 5. X-ray diffraction patterns of powder samples of the three analyzed samples (JIC, ARIX2 and JABU1). Kaolinite is a minor component in all samples. Ka: kaolinite; Goe: goethite, Le: lepidocrocite, Qz: quartz, Gb: gibbsite. mobile - and gaseous - element.

EPR ages were determined for ARIX2 and JIC using paleodose and dose rate values. Considering the pisoliths as being in closed systems for the U-Th and $\mathrm{K}$ content since crystallization time, calculated EPR ages are $1.7 \pm 0.8$ and $7.2 \pm 2.0 \mathrm{Ma}$ for ARIX2 and JIC, respectively (Table 4). If an open system is considered for U and Th, EPR ages become $4.0 \pm 1.9$ and $16.7 \pm 4.7$ Ma for ARIX2 and JIC, respectively (Table 4). Thus, the whole EPR data set covers a large part of the Neogene period.

\section{Discussion}

\subsection{Goethite $(U-T h) / H e$ and kaolinite EPR ages}

\subsubsection{Goethite $(U-T h) / H e$ ages}

The three sites in the Central Amazonia region yielded goethite (UTh)/He ages from Late Miocene to Quaternary. The ARIX2 and JABU1 samples yielded similar raw ages for the six replicates of pisoliths analyzed for each sample (respectively $1.9 \pm 0.4 \mathrm{Ma}$ and 

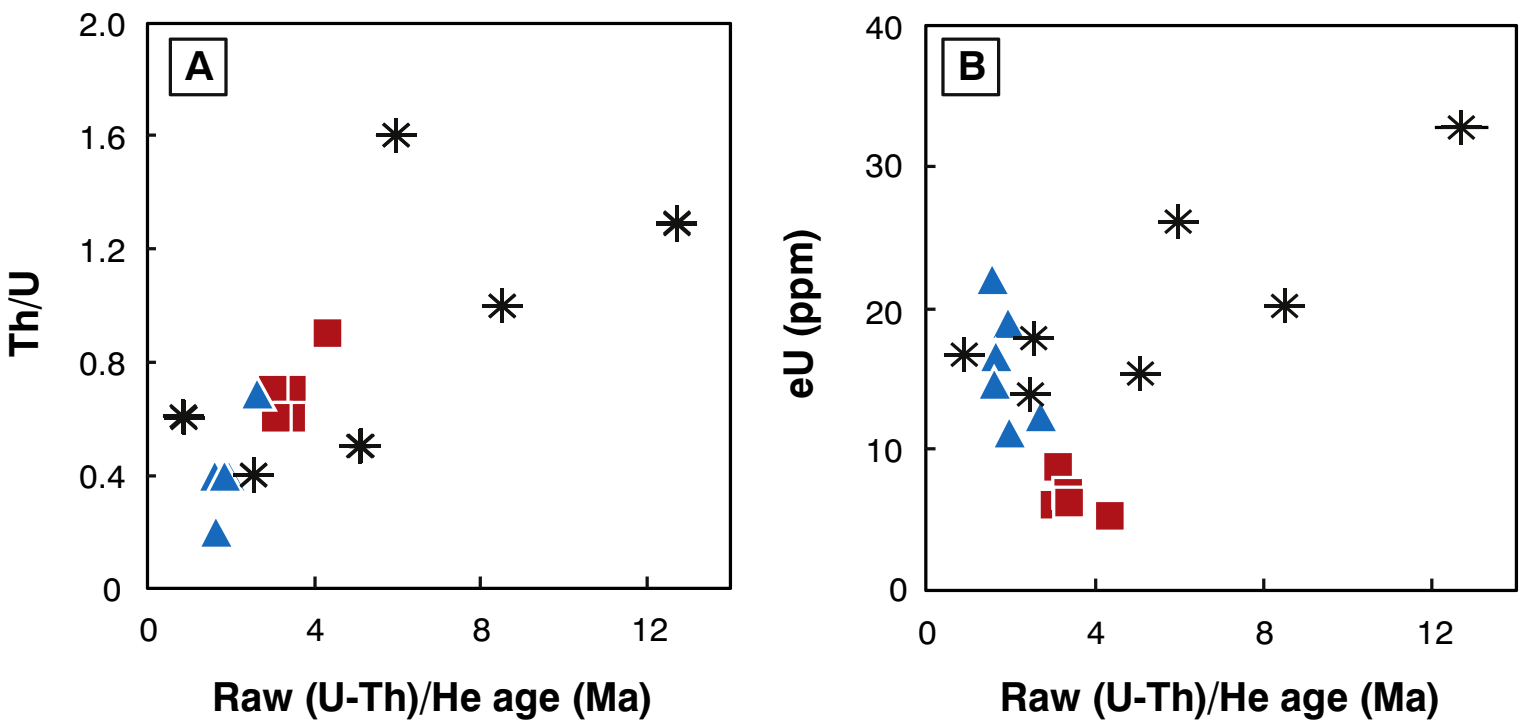

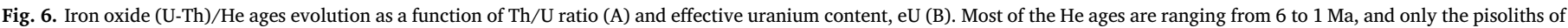
the samples JIC present scattered ages and $\mathrm{Th} / \mathrm{U}$ ratio indicating multiphase weathering processes.

$3.4 \pm 0.5 \mathrm{Ma}$ ), even if the pisolith goethite contents are not similar. As a matter of fact, ARIX2 contains quartz and lepidocrocite, but these phases do not seem to have affected the He system. By contrast, the ages for the JIC sample, upon the crystalline basement, were scattered between $0.9 \pm 0.1$ and $12.7 \pm 0.6 \mathrm{Ma}$ (Fig. 6). The scattered ages are related to the complex structures of pisoliths, reflecting a multi-phased history, that is fully in line with the observations of Hofmann et al. (2017) of pisoliths from paleosoils.

To discuss the obtained ages in terms of crystallization age, a potential correction had to be considered in order to determine the possible He loss by diffusion. With this aim in view, the parameters of the crystallographic characterization of samples were used into a He production/diffusion code (HeFTy; Ketcham, 2005) using a spherical diffusion domain. Thus, the size of coherent domains (Table 2) was considered as a determinant minimal parameter in a worst-case diffusion scenario. The actual size of crystallites, that can be larger than MCD, was not accessible by microscopy. Spherical MCD domains of radius ranging from 6 to $10 \mathrm{~nm}$, were used in the calculation. Using also a $\mathrm{He}$ diffusion coefficient that stands for the retentivity behavior of Shuster et al. (2005) and Vasconcelos et al. (2013), we calculated the amount of He loss by diffusion assuming that all samples presented a surface temperature of $\sim 25^{\circ} \mathrm{C}$ since crystallization (more details can be found in the supplementary section). From the calculation, a He loss of 10 to $25 \%$ is expected for the grain with coherent sizes ranging from 20 to $13 \mathrm{~nm}$, respectively. Accordingly, we made an age correction of $\sim 20 \%$ as reported in the Fig. 9 and the Table 3. Shuster et al. (2005) and more recent references (e.g. Vasconcelos et al., 2013; Monteiro et al., 2014; Riffel et al., 2016) also applied a 5 to $30 \%$ correction for goethite (U$\mathrm{Th}) / \mathrm{He}$ ages based on diffusion data measured directly on the dated crystals. We also used an error of $15 \%$ that represents the sum of analytical error and the error on He diffusion loss estimation. This error also corresponds to the age dispersion (Table 3) for the mean age of ARIX-2 and JABU-1. This correction will not significantly change the age interpretation but will be used in the following discussion, as it reflects better the crystallization age.

The ages presented in Fig. 9 are then corrected values according to diffusion of He in goethite. Using those data, lowering/erosion rates were estimated by dividing the difference of elevation by the difference
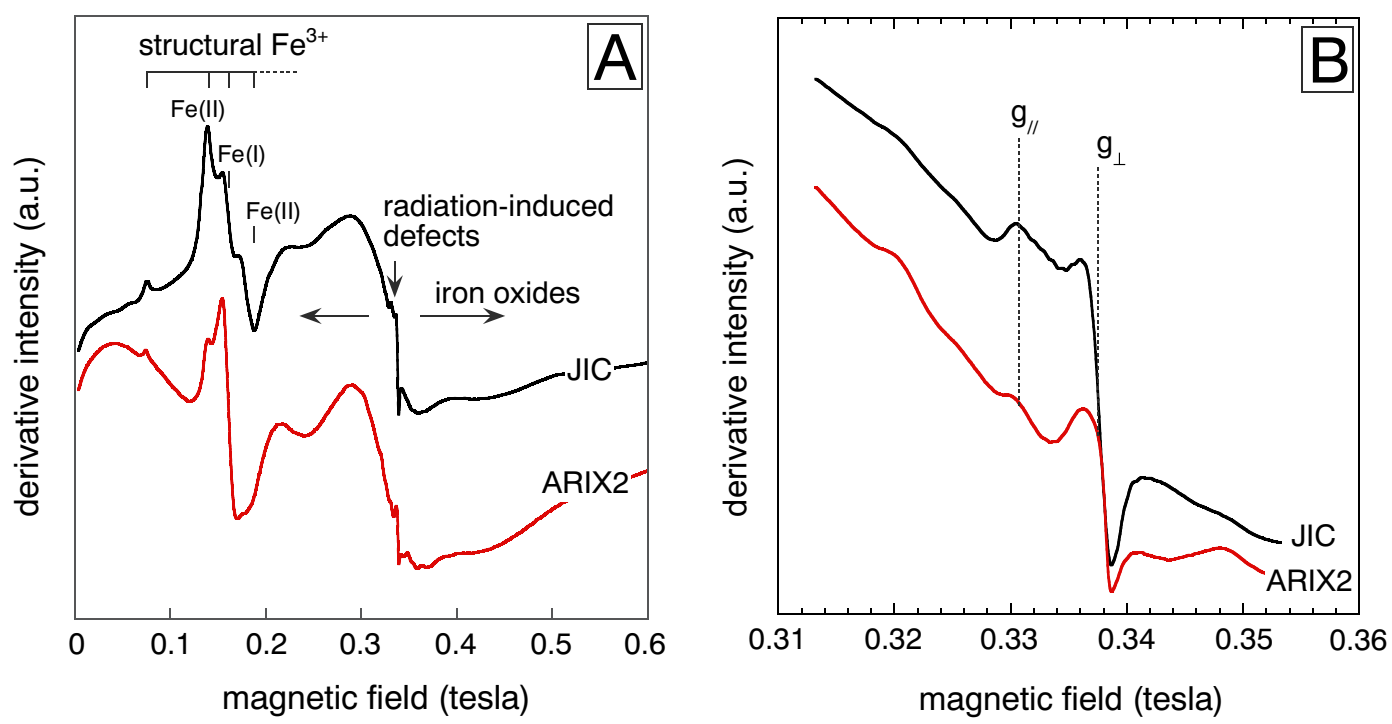

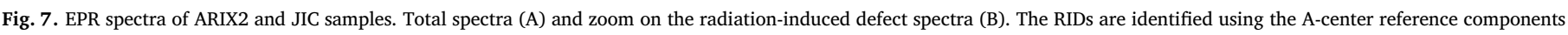
located at $g_{/ /}$and $g_{\perp}$. 

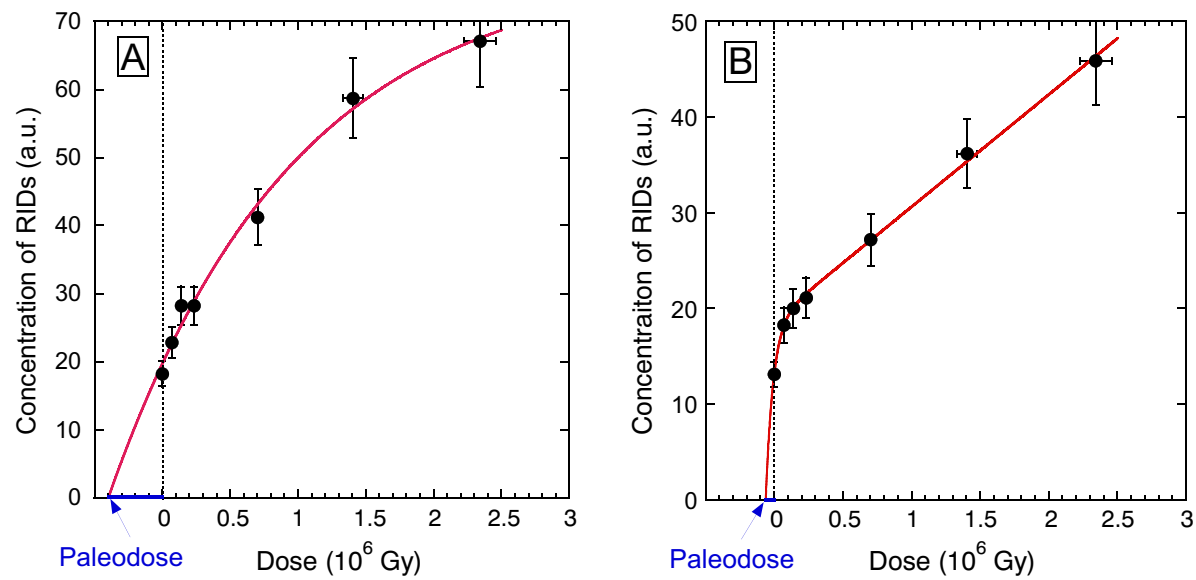

Fig. 8. $\mathrm{He}^{+}$dosimetry curves for JIC (A) and ARIX2 (B) fitted by exponential or exponential + linear functions, respectively. The extrapolation of the curves to the $\mathrm{X}$ axis provides the Paleodose that is directly used in the dating equation.

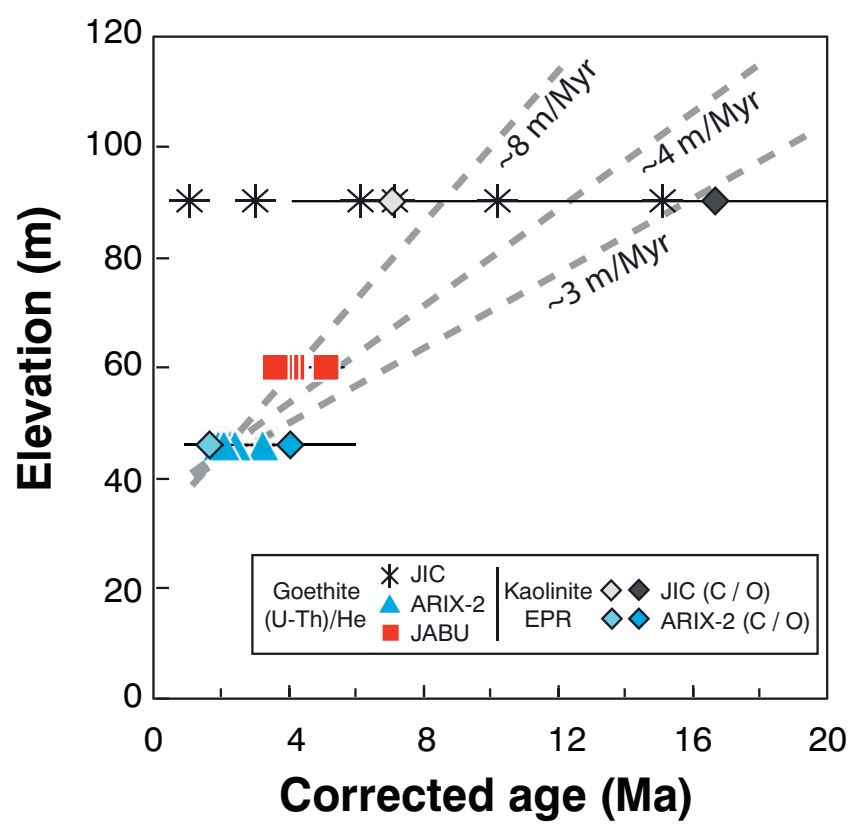

Fig. 9. Evolution of the corrected goethite (U-Th)/He and kaolinite EPR ages as a function of sample elevation. A $20 \%$ correction has been applied to (U-Th)/He age to reflect the He loss by diffusion (see Section 5.1.1). EPR ages are represented considering open (O) and closed (C) systems. Different estimates of the erosion rate are reported.

of ages. They correspond to $\sim 8 \mathrm{~m} / \mathrm{Ma}$ (as assessed from ARIX2 and JABU1 samples), or even lower (about $3 \mathrm{~m} / \mathrm{Ma}$ ) when including JIC value (Fig. 9). When considering corrected ages, it can be observed several episodes of iron oxyhydroxide formation over a 14 Ma period starting at Miocene in JIC. The optical microscopy images (Fig. 3E) clearly show a multi-generation process of pisolith formation with the oldest generation occurring unconformably with a younger regular inclusion. One can also notice that the $\mathrm{Th} / \mathrm{U}$ ratio is also quite scattered and can trace any difference in iron oxide populations or the presence of inclusions (e.g. Monteiro et al., 2014; Riffel et al., 2016).

\subsubsection{Kaolinite EPR ages}

The kaolinite EPR age represents the age of formation of the clay mineral. However, the process of lateritization may be older if early generations of kaolinites were replaced by younger ones. As shown in Table 4, the ages obtained from closed or open systems significantly differ, although for ARIX2 the error bars partly overlap (Fig. 10). However, fully closed systems are not likely to occur according to geochemical studies of $\mathrm{U}$ and $\mathrm{Th}$ isotopes in various laterites, including specifically nodular zones (see e.g. Chabaux et al., 2003; Dequincey et al., 1999; Mathieu et al., 1995). Accordingly, gamma-ray spectrometry showed disequilibria within $U$ decay chain in nodules from a laterite in central Amazonia (Balan et al., 2005). The aperture of decay chains is expected to be sample dependent owing to the real structure of the mineral assemblage. Besides, total loss of radon is also unlikely because the pisoliths selected in our study do not have a fully open porosity but rather a massive internal structure, as observed at the SEM scale (Fig. 4).

The potential influence of two chemical and physical processes on the EPR age was also estimated. First, the leaching of uranium produced during the profile development would imply that the past dose-rate might be higher than the present one. Such a process would yield a younger age value. However, it is assumed that the most sensitive Ubearing phases were weathered early in the profile history. This may have occurred in the successive cycles on the Precambrian parent rock or, in the case of the Içá Formation, in paleolaterites that possibly predated erosion and sediment deposition in the study area.

Second, the presence of water in the porosity naturally decreases the dose rate (Hennig and Grün, 1983). For instance, a $20 \%$ water content, which is a high value, results in about $80 \%$ of the dose rate. However, as water would occur in the porosity of the material located between the pisoliths (see Fig. 3), this effect would apply mostly to gamma and beta radiations whose ranges in matter are in the order of millimeters and centimeters and not on alpha particles whose average range is $20 \mu \mathrm{m}$ in silicates. These $\beta, \gamma$ radiations represent only about $10 \%$ of the total dose from U and Th decay chains (Aitken, 1985); hence the corresponding effect on age would be minor.

\subsubsection{Comparison between goethite (U-Th)/He and kaolinite EPR dating} results

Goethites ages are appropriately determined on separated pisoliths. However, despite the effort for removing the matrix cement, they can also include several generations of iron oxyhydroxides, as revealed by the optical microscopy observations in the JIC sample (see internal unconformities of the pisolith structure, Fig. 3) and by the scattering of (U-Th)/He ages. It is also noticed that the age of kaolinite corresponds to an average value determined on a bulk sample and may contain several generations. The identification of several generations of the same mineral would support a better understanding of the multiple weathering episodes experienced in the profiles. However, only a specific separation of goethite and kaolinite generations in the bulk samples, e.g. by size sorting or microdrilling prior to dating, would address this issue.

Goethite corrected (U-Th)/He and kaolinite EPR ages yield similar values in the limit of uncertainty of the methods, as observed in Figs. 9 and 10, where all data are reported. Considering the open system scenario for the $U$ and Th decay chains, it appears that the ages of kaolinites can be in some cases higher than those of the associated goethites. 


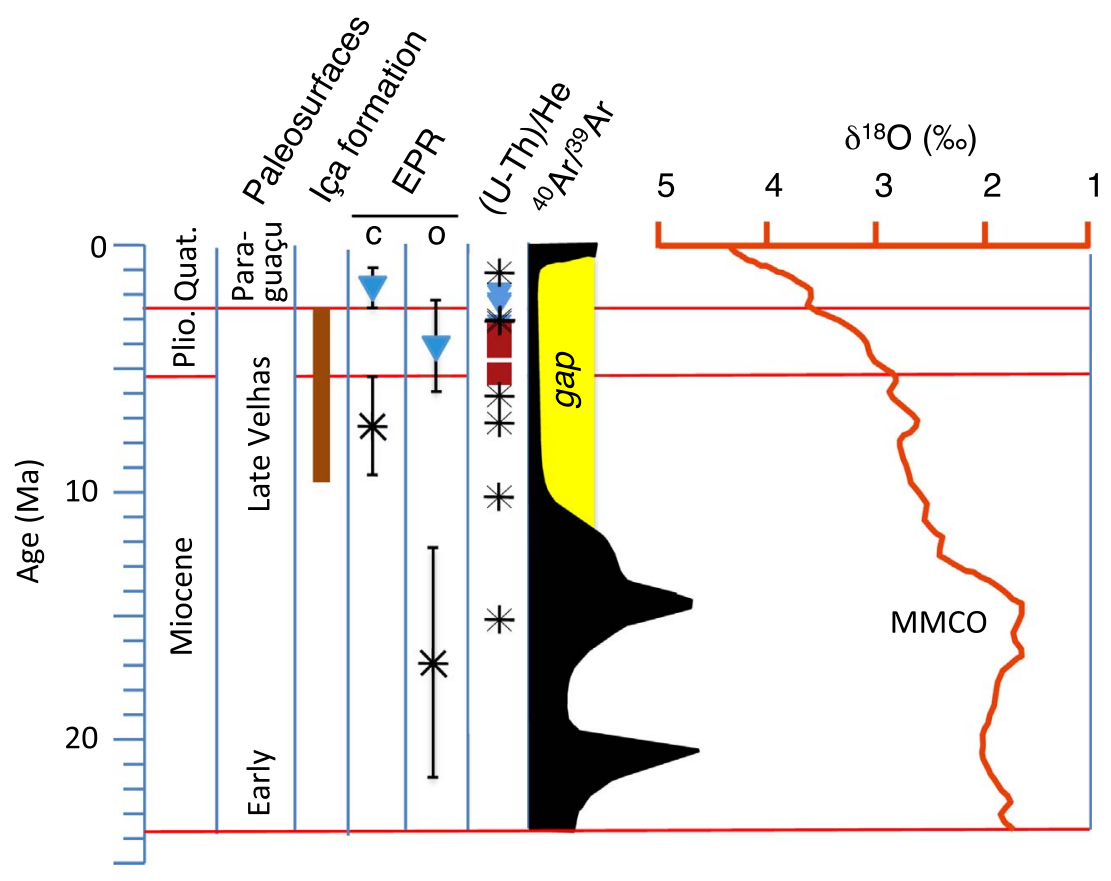

Fig. 10. Chronology of goethite and kaolinite formation obtained by (U-Th)/He and EPR methods (for closed and open scenarii), respectively, compared to periods of erosion paleosurfaces of South America (Théveniaut and Freyssinet, 2002), probability of ${ }^{40} \mathrm{Ar} /{ }^{39} \mathrm{Ar}$ ages of K Mn-oxides in SE Amazonia (Vasconcelos et al., 1994), average curve of benthic $\delta^{18} \mathrm{O}$ (global ocean temperature proxy) after Zachos et al. (2001).

This indicates that the Fe-duricrust could form after the development of the laterite loose horizons, which is a well-known scenario (see e.g. Tardy and Nahon, 1985; Nahon, 1991; Tardy, 1997). In particular, this interpretation is consistent with the model of laterite illustrated by Vasconcelos (1999). It is also consistent with an absence of weathering features of the pisoliths such as internal dissolution voids that could be filled later with clay minerals.

\subsection{Estimate of weathering/erosion rates}

Because the samples exhibit a correlation between age and elevation as illustrated in Fig. 9, it suggests that the corresponding duricrusts are related to different landmark paleosurfaces in a similar organization to that observed previously in French Guiana and Suriname by Théveniaut and Freyssinet $(1999,2002)$. This relation with flat surfaces allows the estimation of surface lowering rates. The corresponding process is thought to consist in an erosion of the surface followed by weathering episode that forms a new Fe-duricrust at a lower elevation. The lowering is thus related to erosion, irrespective of its mechanical or chemical origin. It must be noticed that the duricrust can also deepen by erosion at its surface and production at its base (Théveniaut and Freyssinet, 1999).

Most data exhibit a 3-8 $\mathrm{m} / \mathrm{Ma}$ range of lowering rates (Fig. 9). The values for ARIX2 and JABU1 samples, up to $8 \mathrm{~m} / \mathrm{Ma}$, are fully consistent with the present day values estimations of $6-10 \mathrm{~m} / \mathrm{Ma}$ derived from suspended and dissolved loads of rivers in the Amazon Basin (Théveniaut and Freyssinet (2002) and reference therein). It also appears that these values obtained for erosion rate in our study are in the range of saprolitisation rates reviewed by Thomas (1994). They are similar to weathering rates of $8.8 \mathrm{~m} / \mathrm{Ma}$ measured in a deep lateritic profile in Minas Gerais, Brazil (Carmo and Vasconcelos, 2006), or close to $11.3 \pm 0.5 \mathrm{~m} / \mathrm{Ma}$ determined in Guyana by Théveniaut and Freyssinet (1999). Data are also included in the range of denudation rates estimated for West Africa or many other cratons of the world (Beauvais and Chardon, 2013 and reference therein). The measurement of the erosion rate from ${ }^{10} \mathrm{Be}$ data in quartz in south Amazonia led to mean values of 2.5 and $9.0 \mathrm{~m} / \mathrm{Ma}$ (Braucher et al., 1998). It is noteworthy that ${ }^{3} \mathrm{He}$ data gave very different estimations for the surface erosion rate of Fe-duricrust in the Carajás region located at a $720 \mathrm{~m}$ elevation, with values as low as 0.16 to $0.54 \mathrm{~m} / \mathrm{Ma}$ (Shuster et al.,
2012). The low values for the erosion rates on Carajás result from the fact that the region corresponds to a stable zone with transport limited due to the thickness of regolith covered by a lateritic duricrust (Porto, 2016). The weathering history of this old land surfaces (weathered plateaus remain at an altitude around 600 and $900 \mathrm{~m}$ ) started in Upper Cretaceous ( 70-65 Ma, Ruffet et al., 1996; Vasconcelos et al., 1994).

Data for the JIC sample are more complex. They also include a 3-8 $\mathrm{m}$ /Ma range of lowering rates but younger ages can be lower than those of the other duricrusts. These younger ages would result in meaningless values of lowering rates, as the corresponding high elevation is constant. They correspond to a multi-phased weathering or mobilization of $\mathrm{Fe}$ at the same elevation in periods when erosion did not affect the paleosurface. The lowest erosion rate, $3 \mathrm{~m} / \mathrm{Ma}$, is similar to that obtained by Théveniaut and Freyssinet (2002) on paleosurfaces developed on the Guiana Shield (2-3 m/Ma). In addition, assuming the present conditions of weathering to determine a geochemical mass balance over the whole laterite profile, the weathering front loweringrate in the Manaus region was estimated at $1.6-2.8 \mathrm{~m} / \mathrm{Ma}$ by Lucas (1989).

Thus, the erosion rates estimated in this study belong to a range of values rather than a single value, but they are consistent with those obtained with independent methods, including geochemical mass balance, paleomagnetism or ${ }^{10} \mathrm{Be}$ analyses. They also suggest that the erosion rate was not constant during Neogene because the oldest JIC duricrust yields a lower value than the younger ARIX2 and JABU1 samples.

One important point is about the significance of the obtained rate, in term of weathering propagation or uplift rate. In fact, if we consider only the long-term chronometric data ( $>1 \mathrm{Ma}$; i.e., paleomagnetism, ${ }^{40} \mathrm{Ar} /{ }^{39} \mathrm{Ar}$, (U-Th)/He), similar rates are obtained. However, in contrast with studies in French Guiana and Minas Gerais here we determined rates using samples coming from different profiles (different locations albeit with close elevations). Those weathering/erosion rates may also be tentatively linked to the geodynamic evolution of the Amazonian Basin. However, this is not straightforward, as some authors argue that the Amazonian Basin underwent elevation and eastward tilt since $\sim 30 \mathrm{Ma}$ driven by mantle convection (Shephard et al., 2010) while others suggest a subsidence arising from intraplate tectonics (Costa et al., 2001). 


\subsection{Geological meaning of ages}

The ages found for the ARIX2 and JABU1 duricrusts (Fig. 10) are fully consistent with the age range proposed for the Içá Formation (9.5-2.5 Ma) from stratigraphic correlation with the Madre de Dios Formation in Peru (Campbell et al., 2006). However, it is not known if kaolinites are inherited from ancient laterites or are authigenic. This is not a major issue in our case because goethites formed in the same period as kaolinites, in the limit of method uncertainties, and not long after. Concerning JIC for which several generations of iron oxides were revealed and indicate significant mechanical and/or chemical reworking, the existence of several kaolinite generations is not excluded but cannot be evidenced in our study from the analysis of a bulk sample. It is inferred from our data that the two methods yield consistent results showing that goethites and kaolinites formed in similar periods, within the experimental uncertainties.

The erosion dynamics of the studied regions cannot be clearly connected to the setting of the modern drainage of the Amazon system because several periods have been proposed (see Horbe et al., 2013 and reference therein). Nevertheless, in the region of ARIX2 and JABU1, generalized incision might have coincided with important low sea level stages (down to circa $100 \mathrm{~m}$ ) that occurred after $5 \mathrm{Ma}$ (Haq et al., 1987), a dynamics that was also described for the Quaternary of the Amazon valley (Irion, 2011).

As seen in Fig. 10, our data coincide with intense weathering periods revealed in the Amazon region by other authors (see below). Indeed, several ages of the JIC duricrust determined in this study match the Miocene ${ }^{40} \mathrm{Ar} /{ }^{39} \mathrm{Ar}$ data on Mn-oxides by Vasconcelos et al. (1994). Nevertheless, most of our data are younger and fill the gap below $12 \mathrm{Ma}$ observed by Vasconcelos et al. (1994) and Ruffet et al. (1996) in Amazonia. Based on palaeomagnetism data obtained in profiles developed on the Guiana Shield (French Guiana and Suriname), Théveniaut and Freyssinet $(1999,2002)$, identified two main episodes of laterite formation related to major events at the scale of the South American subcontinent: a cycle of Paleocene-Eocene lateritization corresponding to the Sul-Americana paleosurface and a Miocene cycle assigned to the Late Velhas level (13-5 Ma). In our study, both ARIX2 and JABU1 duricrust would have formed at the end of the Late Velhas period. The corresponding elevations match with the 5-70 m elevations of the Late Velhas level identified in north Brazil by King (1962), Bardossy and Aleva (1990) and Tardy and Roquin (1998). They are lower than the Kaw-B surface of the same period remaining in French Guiana around 200-250 m, but this region also contains contemporaneous terraces at elevation $<50 \mathrm{~m}$ (Théveniaut and Freyssinet, 2002). Moreover, particular ages of JIC iron oxides and kaolinites compare to those of the Manaus latosols (Balan et al., 2005) and de facto suggest a general and important late Miocene/Pliocene episode of lateritization at the scale of the central Amazonia region.

The data from our study can also be tentatively related to paleoclimatic events at global or continental scale. According to Tardy and Roquin (1998), a general context of tropical climate took place in Amazonia since the Late Cretaceous with the formation of duricrusts under contrasting seasons at the Eocene, followed by their dismantling. Hence, the present Neogene data complement this model. However, it must be kept in mind that the relevance of global climate change to relate periods of formation of duricrusts in central Amazonia is not obvious, and that a simple auto-evolution of profiles under nearly constant climate has also been suggested (Nahon, 1991). In addition, a high hematite/goethite ratio in laterites indicates tropical climate with alternate wet and dry seasons (Beauvais, 1999; Beauvais and Roquin, 1996; Beauvais and Tardy, 1993). Accordingly, as goethite largely dominates the mineral assemblage in our duricrusts, this would indicate humid tropical conditions. The comparison with a global parameter such as deep ocean temperature ( $\delta^{18} \mathrm{O}$ proxy) after Zachos et al. (2001) shows a coincidence with the Middle Miocene period (relatively warm and humid period corresponding to the Mid Miocene Climatic
Maximum) but not clearly before (Fig. 10). This event is also suggested when comparing our data to the global continental drainage calculated by Tardy and Roquin (1998).

\section{Conclusions}

This study provides the first intercomparison of goethite (U-Th)/He and kaolinite EPR dating, with special emphasis on pisoliths from ferruginous lateritic duricrusts. The two approaches concern major secondary minerals, cover the Neogene period, and thus represent appropriate methods for dating laterites. Both methods are complementary and supply data consistent with a process of duricrust formation and erosion. Our data are consistent with the geology of the selected parent formations as they give meaningful ages for the Fe-duricrust developed on Içá sediments. Ages of goethites and kaolinites are also close, suggesting a weak offset for processes of formation, within the uncertainties of the methods. In addition, an average erosion rate ranging from 3 to $8 \mathrm{~m} /$ Ma has been derived, which is consistent with published estimates in the Amazon Basin or other cratons of the world. Our data from mineralogy, (U-Th)/He and EPR dating of Fe-duricrust complement the understanding of complex lateritic geosystems in a world-class intertropical basin.

\section{Acknowledgments}

This study has been funded by the Ile de France DIM Oxymore 2014 project, PICS/CNRS ( $\mathrm{N}^{\circ}$ PICS05934) and CAPES-COFECUB $\left(\mathrm{N}^{\circ}\right.$ TE 76012) programs. Cyril Bachelet (CSNSM, Orsay, France) and the ARAMIS team are thanked for the $\mathrm{He}^{+}$irradiations and Nicolas Torbey for XRD measurements. Imène Estève (IMPMC, Paris, France) is thanked for scanning electron microscopy observations. Madeleine Selo (IMPMC, Paris, France) is acknowledged for discussion on induced fission tracks data. L. Tassan-Got is thanked for participation to the discussion on $\mathrm{He}$ diffusion. Anicet Beauvais and the anonymous reviewer are thanked for their constructive reviews that significantly improved this article. This $\mathrm{ms}$ is part of the RECA-ANR-17-CE01-0012-01 project.

\section{Appendix A. Supplementary data}

Supplementary data to this article can be found online at https:// doi.org/10.1016/j.chemgeo.2018.01.004.

\section{References}

Aitken, M.J., 1985. Thermoluminescence dating. In: Studies in Archaeological Science. Academic press, London.

Allard, T., Muller, J.P., 1998. Kaolinite as an in situ dosimeter for past radionuclide migration at the Earth's surface. Appl. Geochem. 13 (6), 751-765.

Allard, T., Balan, E., Calas, G., Fourdrin, C., Morichon, E., Sorieul, S., 2012. Radiationinduced defects in clay minerals: a review. Nucl. Inst. and Meth. in Phys. Res. Section B: Beam Interactions with Materials and Atoms 277, 112-120.

Balan, E., Allard, T., Boizot, B., Morin, G., Muller, J.P., 1999. Structural $\mathrm{Fe}^{3+}$ in natural kaolinites: new insights from electron paramagnetic resonance spectra fitting at $\mathrm{X}$ and Q-band frequencies. Clay Clay Miner. 47, 605-616.

Balan, E., Allard, T., Fristch, E., Selo, M., Falguères, C., Chabaux, F., Pierret, M.C., Calas, G., 2005. Formation and evolution of lateritic profiles in the middle Amazon basin: insights from radiation-induced defects in kaolinite. Geochim. Cosmochim. Acta 69 (9), 2193-2204.

Bardossy, G., Aleva, G.J.J., 1990. Lateritic bauxites. Dev. Econ. Geol. 27 (624 pp).

Beauvais, A., 1999. Geochemical balance of lateritization processes and climatic signatures in weathering profiles overlain by ferricretes in Central Africa. Geochim. Cosmochim. Acta 63 (23-24).

Beauvais, A., Chardon, D., 2013. Modes, tempo, and spatial variability of Cenozoic cratonic denudation: the West African example. Geochem. Geophys. Geosyst. 14 (5), 1590-1608.

Beauvais, A., Roquin, C., 1996. Petrological differentiation patterns and geomorphic districution of ferricretes in Central Africa. Geoderma 73, 63-82.

Beauvais, A., Tardy, Y., 1993. Degradation and dismantling of iron crusts under climatic changes in Central Africa. Chem. Geol. 107, 277-280.

Beauvais, A., Ruffet, G., Henocque, O., Colin, F., 2008. Chemical and physical erosion rhythms of the West African Cenozoic morphogenesis: The ${ }^{40} \mathrm{Ar} /{ }^{39} \mathrm{Ar}$ dating of supergene K-Mn oxides. J. Geophys. Res. Earth Surf. 113 (F4), F04007. 
Beauvais, A., Bonnet, N.J., Chardon, D., Arnaud, N., Jahananda, M., 2016. Very long term stability of passive margin escarpment constrained by ${ }^{40} \mathrm{Ar} /{ }^{39} \mathrm{Ar}$ dating of K-Mn oxides. Geology 44 (4), 299-302.

Berar, J.F., Baldinozzi, G., 1998. XND code: from X-ray laboratory data to incommensurately modulated phases. Rietveld modelling of complex materials. International Union of Crystallography - Commission for Powder Diffraction. Newsletter 20, 3-5.

Berner, R.A., Lassaga, A.C., Garrels, R.M., 1983. The carbonate-silicate geochemical cycle and its effect on atmospheric carbon dioxide over the past 100 million years. Am. J. Sci. 284, 1183-1192.

Bish, D.L., Post, J.E. (Eds.), 1989. Modern powder diffraction. Reviews in Mineralogy, vol. 20 Mineralogical Society of America, Washington, D.C..

Bonnet, N.J., Beauvais, A., Arnaud, N., Chardon, D., Jayananda, M., 2014. First ${ }^{40} \mathrm{Ar} /{ }^{39} \mathrm{Ar}$ dating of intense Late Paleogene lateritic weathering in peninsular India. Earth Planet. Sci. Lett. 386, 126-137.

Bonnet, N.J., Beauvais, A., Arnaud, N., Chardon, D., Jayananda, M., 2016. Cenozoic lateritic weathering and erosion history of peninsular India for ${ }^{40} \mathrm{Ar} /{ }^{39} \mathrm{Ar}$ dating of supergene K-Mn oxides. Chem. Geol. 446, 18-32.

Braucher, R., Bourlès, D.L., Colin, F., Brown, E.T., Boulangé, B., 1998. Brazilian laterite dynamics using in situ-produced ${ }^{10} \mathrm{Be}$. Earth Planet. Sci. Lett. 163, 197-205.

Calas, G., 1988. Electron paramagnetic resonance. In: Hawthorne, F.C. (Ed.), Spectroscopic Methods in Mineralogy and Geology. Reviews in Mineralogy. Mineralogical Society of America, Washington D.C, pp. 513-571.

Campbell, K.E., Frailey, C.D., Romero-Pittman, L., 2006. The Pan-Amazonian Ucayal Peneplain, late Neogene sedimentation in Amazonia and the birth of the modern Amazon river system. Palaeogeogr. Palaeoclimatol. Palaeoecol. 239, 166-219.

Carmo, I.d.O., Vasconcelos, P.M., 2006. ${ }^{40} \mathrm{Ar} /{ }^{39} \mathrm{Ar}$ geochronology constraints on late miocene weathering rates in Minas Gerais, Brazil. Earth Planet. Sci. Lett. 241, 80-94.

Chabaux, F., Dequincey, O., Lévèque, J.J., Leprun, J.C., Clauer, N., Riotte, J., Paquet, H., 2003. Tracing and dating recent chemical transfers in weathering profiles by traceelement geochemistry and ${ }^{238} \mathrm{U}_{-}{ }^{234} \mathrm{U}-{ }^{230} \mathrm{Th}$ disequilibria: the example of the Kaya lateritic toposequence (Burkina-Faso). Compte-Rendus Acad. Sci., Geoscience. 335, 1219-1231.

Clozel, B., Allard, T., Muller, J.P., 1994. Nature and stability of radiation-induced defects in natural kaolinites: new results and a reappraisal of published works. Clay Clay Miner. 42 (6), 657-666.

Cornu, S., Montagne, D., Vasconcelos, P.M., 2009. Dating constituent formation in soils to determine rates of soil processes: a review. Geoderma 153, 293-303.

Costa, M.L., Moraes, E.L., 1998. Mineralogy, geochemistry and genesis of kaolins from the Amazon region. Mineral. Deposita 33 (3), 283-297.

Costa, J.B.S., Bemerguy, R.L., Hasui, Y., da Silva Borges, M., 2001. Tectonics and paleogeography along the Amazon river. J. S. Am. Earth Sci. 14, 335-347.

Costa, M.L., Lima Sousa, D.J., Angelica, R.S., 2009. The contribution of lateritization processes to the formation of the kaolin deposits from eastern Amazon. J. S. Am. Earth Sci. 27, 219-234.

Costa, M.L., Cruz, G.S., Almeida, H.D.F., Poellmann, H., 2014. On the geology, mineralogy and geochemistry of the bauxite-bearing regolith in the lower Amazon Basin: evidence of genetic relationships. J. Geochem. Explor. 146, 58-74.

Cozzuol, M.A., 2006. The Acre vertebrate fauna; age, diversity, and geography. J. S. Am. Earth Sci. 21 (3), 185-203.

CPRM, 2006. http://geowebapp.cprm.gov.br/ViewerWEB/.

Cunha, F.M.B., Gonzaga, F.G., Coutinho, L.F.C., Feijó, F.J., 1994. Bacia do Amazonas. Bol. Geoci. Petrobras 8 (1), 47-55.

Cunha, P.R.C., Melo, J.H.G., Silva, O.B., 2007. Bacia do Amazonas. Bol. Geoci. Petrobras 15 (2), 227-251.

Daemon, R.F., 1975. Contribuição à datação da Formação Alter do Chão, Bacia do Amazonas. Rev. Bras. Geosci. 5 (2), 58-84.

Dequincey, O., Chabaux, F., Clauer, N., Liewig, N., Muller, J.P., 1999. Dating of weath ering profiles by radioactive disequilibria: contribution of the study of authigenic mineral fractions. C.R. Acad. Sci., Ser. IIa: Sci. Terre Planets 328, 679-685.

Dino, R., Soares, E.A.A., Antonioli, L., Riccomini, C., Nogueira, A.C.R., 2012. Palynostratigraphy and sedimentary facies of Middle Miocene fluvial deposits of the Amazonas Basin, Brazil. J. S. Am. Earth Sci. 34, 61-80.

Duval, M., 2012. Dose response curve of the ESR signal of the aluminum center in quartz grains extracted from sediment. Ancient TL 30 (2), 41-49.

Farley, K., 2002. (U-Th)/He dating: Techniques, calibrations, and applications. In: Noble Gases in Geochemistry and Cosmochemistry. Rev. Mineral. Geochem. (Washington). 47(1), pp. 819-844

Farley, K.A., Flowers, R.M., 2012. (U-Th)/Ne and multidomain (U-Th)/He systematics of a hydrothermal hematite from eastern Grand Canyon. Earth Planet. Sci. Lett. 359, 131-140.

Figueiredo, J.J.P., Zalán, P.V., Soares, E.F., 2007. Foz do Amazonas basin. Bol. Geoci. Petrobras 15 (2), 299-309.

Figueiredo, J., Hoorn, C., van der Ven, P., Soares, E., 2009. Late Miocene onset of the Amazon River and the Amazon deep-sea fan: evidence from the Foz do Amazonas Basin. Geology 37 (7), 619-622.

Fritsch, E., Herbillon, A.J., do Nascimento, N.R., Grimaldi, M., Melfi, A.J., 2007. From plinthic acrisols to plinthosols and gleysols: iron and groundwater dynamics in the tertiary sediments of the upper Amazon basin. Eurasian Soil Sci. 58, 989-1006.

Fritsch, E., Balan, E., do Nascimento, N.R., Allard, T., Bardy, M., Bueno, G., Derenne, S., Melfi, A.J., 2011. Deciphering the weathering processes using environmental mineralogy and geochemistry: towards an integrated model of laterite and podzol genesis in the Upper Amazon Basin. Comptes Rendus Acad. Sci. Geoscience 343 (2-3), 188-198.

Gautheron, C., Tassan-Got, L., Farlet, K.A., 2006. (U-Th)/Ne chronometry. Earth Planet. Sci. Lett. 243, 520-535.
Gautheron, C., Espurt, N., Barabarand, J., Roddaz, M., Baby, P., Brusset, S., Tassan-Got, L., Douville, E., 2013. Direct dating of thick- and thin-skin thrusts in the Peruvian Subandean zone through apatite (U-Th)/He and fission track thermochronometry. Basin Res. 25 (4), 419-435.

Girard, J.-P., Freyssinet, P., Chazot, G., 2000. Unraveling climatic changes from intraprofile variation in oxygen and hydrogen isotopic composition of goethite and kaolinite in laterites: an integrated study from Yaou, French Guiana. Geochim. Cosmochim. Acta 64 (3), 409-426.

Girard, J.-P., Freyssinet, P., Morillon, A.C., 2002. Oxygen isotope study of Cayenne duricrust paleosurfaces: implications for past climate and laterization processes over French Guiana. Chem. Geol. 191, 329-343.

Haq, B.U., Hardenbol, J., Vail, P.R., 1987. Chronology of fluctuation sea levels since the Triassic. Science 235, 1156-1167.

Heinrich, S., Zonneveld, K.A.F., 2013. Influence of the Amazon River development and constriction of the Central American Seaway on Middle/Late Miocene oceanic conditions at the Ceara Rise. Palaeogeogr. Palaeoclimatol. Palaeoecol. 386 (0), 599-606.

Hennig, G.J., Grün, R., 1983. ESR dating in quaternary geology. Quat. Sci. Rev. 2 (2-3), $157-238$.

Hofmann, F., Reichenbacher, B., Farley, K.A., 2017. Evidence for > 5Ma paleo-exposure of an Eocene-Miocene paleosol of the Bohnerz formation, Switzerland. Earth Planet. Sci. $465,168-175$.

Hoorn, C., et al., 2010. Amazonia through time: Andean uplift, climate change, landscape evolution, and biodiversity. Science 330 (6006), 927-931.

Horbe, A.M.C., Nogueira, A.C.R., Horbe, M.A., Costa, M.L., Suguio, K., 2001. A laterização na gênese das superfícies de aplanamento da região de Presidente Figueiredo - Vila Balbina, nordeste do Amazonas. In: Costa, M.L., Angélica, R.S. (Eds.), (Orgs.). Contribuiç̃ões à geologia da Amazônia. Belém: FINEP-SBG/NO, v. 2. cap.5, pp. 145-176.

Horbe, A.M.C., Horbe, M.A., Suguio, K., 2003. Origem dos depósitos de areias brancas no nordeste do Amazonas. Rev. Bras. Geosci. 33 (1), 41-50.

Horbe, A.M.C., Motta, M.B., de Almeida, C.M., Dantas, E.L., Vieira, L.C., 2013. Provenance of Pliocene and recent sedimentary deposits in western Amazônia, Brazil: consequences for the paleodrainage of the Solimões-Amazonas River. Sediment. Geol. 296, 9-20.

Irion, G., 1984. Clay minerals of Amazonian soils. In: Sioli, H. (Ed.), The Amazon, Limnology and Landscape Ecology of a Mighty Tropical River and its Basin. Dr W. Junk Publishers, pp. 537-580.

Irion, G., 2011. Development of the Amazon valley during the middle to late quaternary: sedimentological and climatological observations. In: Junk, W.J., Piedade, M.T.F., Wittmann, F., Schöngart, J., Parolin, P. (Eds.), Amazonian Floodplain Forests. Ecophysiology, Biodiversity and Sustainable Management. Springer Science + business media B.V. 2010. XVIII, pp. 27-42.

Ishida, D.A., Montes, C.R., Lucas, Y., Pereira, O.J.R., Merdy, P., Melfi, A.J., 2014. Genetic relationships between ferralsols, podzols and white kaolin in Amazonia. Eur. J. Soil Sci. 65, 706-717.

Ivanovich, M., Harmon, R.S., 1992. Uranium-series disequilibrium. In: Applications to Earth, Marine, and Environmental Sciences. Clarendon Press, Oxford (910 pp.).

Ketcham, R.A., 2005. Forward and inverse modelling of low-temperature thermochronology data. In: Reiners, P.W., Ehlers, T.A. (Eds.), Low Temperature Thermochronology: Techniques, Interpretations and Applications: Reviews in Mineralogy and Geochemistry, pp. 275-314.

Ketcham, R.A., Gautheron, C., Tassan-Got, L., 2011. Accounting for long alpha-particle stopping distances in (U-Th-Sm)/He geochronology: refinement of the baseline case. Geochim. Cosmochim. Acta 75 (24), 7779-7791.

King, L.C., 1956. A geomorfologia do Brasil oriental. Rev. Bras. Geogr. 18 (2), 147-266.

King, L.C., 1962. Morphology of the Earth. Oliver and Boyd, London (699 pp).

Kroonenberg, S.B., Roever, E.W.F.D., 2010. Geological evolution of the Amazonian Craton. In: Hoorn, C., Wesselingh, F.P. (Eds.), Amazonia: Landscape and Species Evolution: A Look into the Past, pp. 9-28.

Latrubesse, E.M., da Silva, S.A.F., Cozzuol, M., Absy, M.L., 2007. Late Miocene continental sedimentation in southwestern Amazonia and its regional significance; biotic and geological evidence. J. S. Am. Earth Sci. 23 (1), 61-80.

Lucas, Y., 1989. Systèmes pédologiques en Amazonie brésilienne, Equilibres, déséquilibres et transformations, Université de Poitiers. Unpublished PhD. (157 pp).

Lucas, Y., Montes, C.R., Mounier, S., Cazalet, M., Loustau, M., Ishida, D., Achard, R., Garnier, C., Coulomb, B., Melfi, A.J., 2012. Biogeochemistry of an Amazonian podzolferralsol soil system with white kaolin. Biogeosciences 9 (9), 3705-3720.

Mathieu, D., Bernat, M., Nahon, D., 1995. Short-lived U and Th isotope distribution in a tropical laterite derived from granite (Pitinga river basin, Amazonia, Brazil): application to assessment of weathering rate. Earth Planet. Sci. Lett. 136, 703-714.

McFarlane, M.J., 1976. Laterite and Landscape. Academic Press Inc, London.

Mehra, O.P., Jackson, M.L., 1960. Iron oxide removal from soils and clays by dithionitecitrate buffered with sodium bicarbonate. Clay Clay Miner. 7, 317-327.

Milani, E.J., Zalan, P.V., 1999. An outline of the geology and petroleum systems of the Paleozoic interior basins of South America. Episodes 22 (3), 199-205.

Monteiro, H.S., Vasconcelos, P.M., Farley, K.A., Spier, C.A., Mello, C.L., 2014. (U-Th)/He geochronology of goethite and the origin and evolution of cangas. Geochim. Cosmochim. Acta 131 (0), 267-289.

Muller, J.P., Calas, G., 1993. Genetic significance of paramagnetic centers in kaolinites In: Murray, H.H., Bundy, W., Harvey, C. (Eds.), Kaolin Genesis and Utilization. The Clay Minerals Society, Boulder, pp. 261-289.

Nahon, D.B., 1991. Introduction to the Petrology of Soils and Chemical Weathering. John Wiley \& Sons, New York.

Nahon, D.B., 2003. Altérations dans la zone tropicale. Signification à travers les mécanismes anciens et/ou encore actuels. Comptes Rendus Acad. Sci. Geoscience $335,1109-1119$. 
Pedro, G., 1987. Géochimie, mineralogie et organization des sols. Aspects coordonnés des problèmes pédogénétiques. In: Cahiers de l'ORSTOM. Série pédologie., XXIII (3), pp. 169-186.

Pidgeon, R.T., Brander, T., Lippolt, H.J., 2004. Late Miocene (U-Th)/He ages of ferruginous nodules from lateritic duricrust, Darling Range, Western Australia. Aust. J. Earth Sci. 51, 901-909.

Porto, C.G., 2016. Geochemical exploration challenges in the regolith dominated Igarapé Bahia gold deposit, Carajás, Brazil. Ore Geol. Rev. 73 (Part 3), 432-450.

Price, P.B., Walker, R.M., 1963. A simple method for measuring low uranium concentrations in natural crystals. Appl. Phys. Lett. 2, 23-25.

Riffel, S.B., Vasconcelos, P.M., Carmo, I.O., Farley, K.A., 2016. Goethite (U-Th)/He geochronology and precipitation mechanisms during weathering of basalts. Chem. Geol. 446, 18-32.

Rossetti, D.F., Mann de Toledo, P., Góes, A.M., 2005. New geological framework for Western Amazonia (Brazil) and implications for biogeography and evolution. Quat. Res. 63 (1), 78-89.

Ruffet, G., Innocent, C., Michard, A., Féud, G., Beauvais, A., Nahon, D., Hamelin, B., 1996. A geochronological ${ }^{40} \mathrm{Ar} /{ }^{39} \mathrm{Ar}$ and ${ }^{87} \mathrm{Rh} /{ }^{87} \mathrm{Sr}$ study of K-Mn oxides from the weathering sequence of Azul, Brazil. Geochim. Cosmochim. Acta 60 (12), 2219-2232.

Sakoda, A., Ishimori, Y., Yamaoka, K., 2011. A comprehensive review of radon emanation measurements for mineral, rock, soil, mill tailing and fly ash. Appl. Radiat. Isot. 69, 1422-1435.

Schmidt, P.W., Embleton, B.J.J., 1976. Palaeomagnetic results from sediments of the Perth basin, western Australia, and their bearing on the timing of regional lateritisation. Palaeogeogr. Palaeoclimatol. Palaeoecol. 19, 257-273.

Sélo, M., 1983. La fission nucléaire et sa signification en Géochronologie, Paleothermométrie et Géochimie, Applications à l'étude particulière des basaltes océaniques. Unpublished phD Thesis. University Paris VI.

Shephard, G.E., Müller, R.D., Liu, L., Gurnis, M., 2010. Miocene drainage reversal of the Amazon River driven by plate-mantle interaction. Nat. Geosci. 3, 870-975.

Shuster, D.L., Vasconcelos, P.M., Heim, J.A., Farley, K.A., 2005. Weathering geochronology by (U-Th)/He dating of goethite. Geochim. Cosmochim. Acta 69 (3), 659-673.

Shuster, D.L., Farley, K.A., Vasconcelos, P.K., Balco, G., Monteiro, H.S., Waltenberg, K. Stone, J.O., 2012. Cosmogenic ${ }^{3} \mathrm{He}$ in hematite and goethite from Brazilian "canga" duricrust demonstrates the extreme stability of these surfaces. Earth Planet. Sci. Lett. 329-330, 41-50.
Tardy, Y., 1997. Petrology of Laterites and Tropical Soils. Balkema, Amsterdam.

Tardy, Y., Nahon, D., 1985. Geochemistry of laterites, stability of Al-goethite, Al-hematite, and $\mathrm{Fe}^{3+}$-kaolinite in bauxites and ferricretes; an approach to the mechanism of concretion formation. Amer. J. Sci. 285 (10), 865-903.

Tardy, Y., Roquin, C., 1998. Dérive des continents, Paléoclimats et alterations tropicales. BRGM, Orléans.

Théveniaut, H., Freyssinet, P., 1999. Paleomagnetism applied to lateritic profiles to assess saprolite and duricrust formation processes: the example of Mont Baduel profile (French Guiana). Palaeogeogr. Palaeoclimatol. Palaeoecol. 148 (4), 209-231.

Théveniaut, H., Freyssinet, P., 2002. Timing of lateritization on the Guiana shield: synthesis of paleomagnetic results from French Guiana and Suriname. Palaeogeogr. Palaeoclimatol. Palaeoecol. 178 (1-2), 91-117.

Thomas, M.F., 1994. Geomorphology in the Tropics: A Study of Weathering and Denudation in Low Latitudes. John Wiley \& Sons.

Vasconcelos, P.M., 1999. K-Ar and ${ }^{40} \mathrm{Ar} /{ }^{39} \mathrm{Ar}$ geochronology of weathering processes. Annu. Rev. Earth Planet. Sci. 27, 183-229.

Vasconcelos, P.M., Renne, P.R., Brimhall, G.H., Becker, T.A., 1994. Direct dating of weathering phenomena by ${ }^{40} \mathrm{Ar} /{ }^{39} \mathrm{Ar}$ and $\mathrm{K}$-Ar analysis of supergene K-Mn oxides. Geochim. Cosmochim. Acta 58 (6), 1635-1665.

Vasconcelos, P.M., Heim, J.A., Farley, K.A., Monteiro, H., Waltenberg, K., 2013. ${ }^{40} \mathrm{Ar} /{ }^{39} \mathrm{Ar}$ and $(\mathrm{U}-\mathrm{Th}) / \mathrm{He}-{ }^{4} \mathrm{He} /{ }^{3} \mathrm{He}$ geochronology of landscape evolution and channel iron deposit genesis at Lynn Peak, Western Australia. Geochim. Cosmochim. Acta $117,283-312$

Vasconcelos, P.M., Reich, M., Suster, D.L., 2015. The paleoclimatic signatures of supergene metal deposits. Elements 11, 317-322.

Yapp, C.J., 2000. Climatic implications of surface domains in arrays of $\delta \mathrm{D}$ and $\delta^{18} \mathrm{O}$ from hydroxyl minerals: Goethite as an example. Geochim. Cosmochim. Acta 64 (12), 2009-2025.

Zachos, J., Pagani, M., Sloan, L., Thomas, E., Billups, K., 2001. Trends, rhythms and aberrations in global climate 65 Ma to present. Science 292, 686-693.

Zhao, L., Hong, H., Fang, Q., Yin, K., Wang, C., Li, Z., Torrent, J., Cheng, F., Algeo, T.J., 2017. Monsoonal climate evolution in southern China since 1.2 Ma: New constraints from Fe-oxide records in red earth sediments from the Shengli section, Chengdu Basin. Palaeogeogr. Palaeoclimatol. Palaeoecol. 473, 1-15.

Ziegler, J.F., Ziegler, M.D., Biersack, J.P., 2010. SRIM - the stopping and range of ions in matter. Nucl. Instrum. Methods Phys. Res., Sect. B 268 (11-12), 1818-1823. 